University of Montana

ScholarWorks at University of Montana

Graduate Student Theses, Dissertations, \&

Professional Papers

1967

\title{
Thermoregulation of the red-breasted nuthatch (Sitta canadensis)
}

John N. Mugaas

The University of Montana

Follow this and additional works at: https://scholarworks.umt.edu/etd

Let us know how access to this document benefits you.

\section{Recommended Citation}

Mugaas, John N., "Thermoregulation of the red-breasted nuthatch (Sitta canadensis)" (1967). Graduate

Student Theses, Dissertations, \& Professional Papers. 6918.

https://scholarworks.umt.edu/etd/6918

This Thesis is brought to you for free and open access by the Graduate School at ScholarWorks at University of Montana. It has been accepted for inclusion in Graduate Student Theses, Dissertations, \& Professional Papers by an authorized administrator of ScholarWorks at University of Montana. For more information, please contact

scholarworks@mso.umt.edu. 


$$
22:
$$

THERMOREGULATION

OF THE RED-BREASTED NUTHATCH (Sitta canadensis:

by

John N. Mugaas

B.A. University of Montana, 1965

Presented in partial fulfillment of the requirements for the

degree of Master of Arts in Zoology

UNIVERSITY OF MONTANA

1967

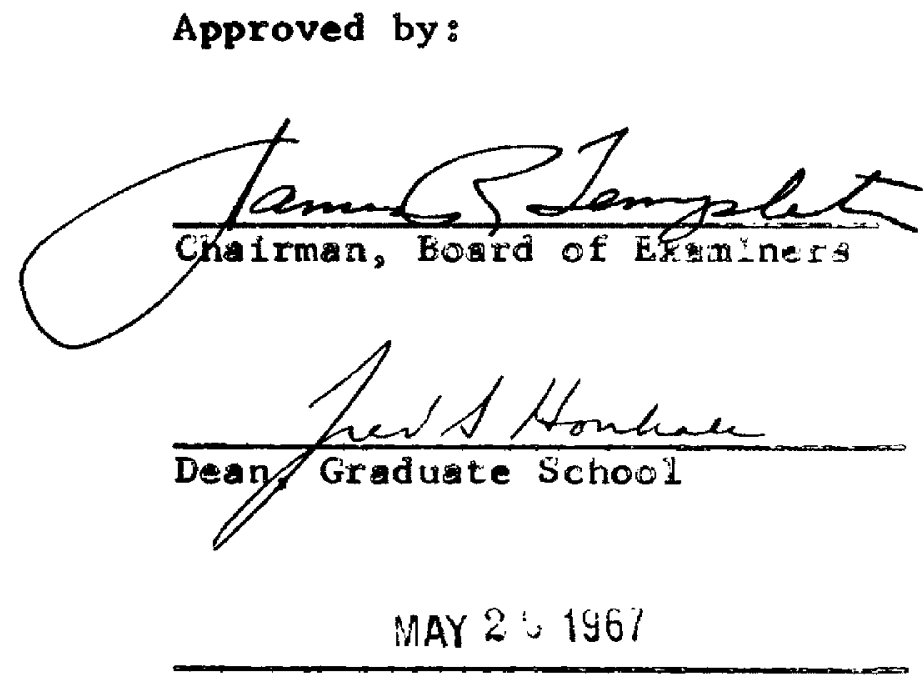

Date 


\section{All rights reserved}

\section{INFORMATION TO ALL USERS}

The quality of this reproduction is dependent upon the quality of the copy submitted.

In the unlikely event that the author did not send a complete manuscript and there are missing pages, these will be noted. Also, if material had to be removed, a note will indicate the deletion.

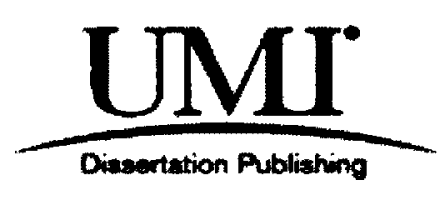

\section{UMI EP37719}

Published by ProQuest LLC (2013). Copyright in the Dissertation held by the Author.

Microform Edition (C) ProQuest LLC.

All rights reserved. This work is protected against unauthorized copying under Title 17, United States Code

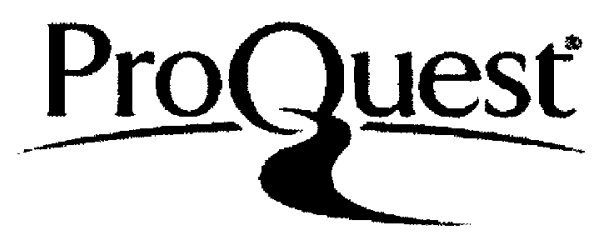

ProQuest LLC.

789 East Eisenhower Parkway

P.O. Box 1346

Ann Arbor, MI $48106-1346$ 


\section{ACKNOWLEDGEMENTS}

I wish to thank Dr. James R. Templeton for his interest and gsidance throughout this study, and his help in editing and preparing this manuscript. I also wish to thank Dr. Hoffmann, Dr. Pfeiffer, Dr. Herreid, and Dr. Reinhardt for their helpful criticisms. Thanks are due to David Murrish for his help in assembling the apparatis, and sim Hemming for his aid and advice in trapping the birds. Special thanks go to my wife, Lynn, for her time lost tending the traps, and her patience and help during the irregular hours $I$ spent completing portions of this study. 
LIST OF TABLES ..................... . . . . . . . . . .

LIST OF FIGURES ........................ vii

INTRODUCTION ....................... 1

I. Traditiona 1 and Contemporary Views of Homeothermy

and Thermoregulation ................. 1

A. Homeothermy and body temperature . . . . . . . . . . 1

1. Birds as homeotherms . . . . . . . . . . . . . . . 1

2. The body-temperature, body-weight relationship... 2

3. Cyclic varfations in the body temperatures of birds and mammals. . . . . . . . . . . . . 6

B. Thermoregulation .................7 7

1. The logistics of thermoregulation. . . . . . . . 7

a. The adjustment of heat gain and heat loss. . . 8

b. Seasonal and climatic thermoregulation . . . . . 10

2. Calorimetry of the body heat of homeotherms. . . . . 11

a. The historical development of indirect

calorimetry. . . . . . . . . . . . . . . 11

b. The respiratory quotient . . . . . . . . . 12

(1) Carbohydrate respiratory quotient . . . . 13

(2) Protein respiratory quotient. . . . . . 13

(3) Fat respiratory quotient. . . . . . . . 13

3. The calculation of heat production by indirect

calorimetry. . . . . . . . . . . . . . . . 14

4. The role of the respiratory quotient in indirect

calorimetric measurements. . . . . . . . . . . . 15

a. Finding the caloric equivalent of oxygen

for birds. . . . . . . . . . . . . . 15

b. Respiratory quotient values below $0.71 \ldots 16$

c. Respiratory quotient values above 1.0. . . . . . 17

d. The value of the respiratory quotient as an index of the intermediary metabolism. . . . 18

e. The effects of low ambient temperatures on

the respiratory quotient ........... 18

5. Thermoregulation at ambient temperatures below

the body temperature . . . . . . . . . . . . . 20

a. The zone of thermal neutrality, the resting metabolic rate, and physical thermoregulation. . 20

b. Fur and feathers as insulation .........21

c. The use of the extremities in controlling heat exchange. . . . . . . . . . . . . . 22

d. Chemical thermoregulation. . . . . . . . . . . 24

6. Graphical representation of thermoregulation at ambient temperatures below the body temperature. . . 27 
a. The Newtonián model. . . . . . . . . . . . 27

b. Chemical and physical acclimatization. . . 29

c. West's model of acclimatization for sma 11 birds. . ............... 29

d. The validity of Newton's Law of Cooling as applied to homeotherms........... 33

e. Thermal conductance and total insulation of small birds and mammals . . . . . . . . . 34

7. Thermoregulation at ambient temperatures above

and equal to the body temperature. . . . . . . , 35

a. Hypothermia vs. hyperthermia . . . . . . . 35

b. Regulating the body temperature at high

ambient temperatures . . . . . . . . . . 36

(1) Passive heat loss........... 36

(2) Evaporative heat loss......... 37

(3) The use of hyperthermia in aiding heat loss.............. . 38

(4) The effectiveness of evaporative cooling in birds. . . . . . . . . . 39

C. The standard or minimal resting metabolic rate and

its relation to the environment. . . . . . . . . . . 40

1. The standard or minimal resting metabolism. . 40

a. The metabolic rate, weight relationship of manma ls . . . . . . . . . . . . . . . . . 40

b. The metabolic rate, weight relationship of birds... . . . . . . . . . . . 42

(1) The Brody-Proctor equation. . . . . . 42

(2) The King-Farner equation. . . . . . . . 43

(3) The Lasiewski-Dawson equation..... 43

2. Resting metabolism and climate... . . . . . . 45

a. Adaptation of the metabolic rate by hibernators. . . . . . . . ... . . . . 45

b. Adaptation of the metabolic rate for life in hot arid climates... . . . . . . . . 46

II. The Present Study . . . . . . . . . . . . . . . . . . . 48

MATERIALS AND METHODS. . . . . . . . . . . . . . . . . . . 51

I. Trapping and Maintainance................. . 51

II. Experimental Procedures. . . . . . . . . . . . . . . 53

RESULTS. . . . . . . . . . . . . . . . . . . . . 61

I. Oxygen Consumption. . . . . . . . . . . . . . . . 61

II. Evaporative Water Loss. . . . . . . . . . . . . . . . 61

III. The Respiratory Quotient. . . . . . . . . . . . . . 66 
I. The Resting (basal) Metabolic Rate............... 39

II. Energy Requirements in the cold................. 9

III. Oxygen Consumption at High Temperatures. . . . . . . . . . . . 69

IV. Oxygen Consumption of Summer and Winter Birds. . . . . . . . . 7 .

V. Evaporative Water Loss and Dissipation of Metabolic Heat. . . 73

A. Evaporative water loss. . . . . . . . . . . . . .

B. Dissipation of metabolic hest. . . . . . . . . . . . . ;

IV. The Respiratory Quotient . . . . . . . . . . . . . . is SUMMARY AND COHCLUSIONS . . . . . . . . . . . . . . . . . 8 ? LITERATURE CITED. . . . . . . . . . . . . . . . . . . . . . . 8, 


\section{LIST OF TABLES}

TABLE

PAGE

1. The basal metabolic rate of the red-breasted nuthatch

and its relationship to other predicted values . . . . . . . 70

2. A summary of the respiratory quotient values below $0.65 . . .81$ 


\section{LIST OF FIGURES}

1. The relation of body temperature to weight in birds and mannals. . . . . . . . . . . . . . . . . 5

2. Models of metabolic and insulative thermoregulation. . . 32

3. Schenatic diagram of the apparatus . . . . . . . . . 57

4. Oxygen consumption of the red-breasted nuthatch in $\mathrm{cc} \mathrm{O}_{2} / \mathrm{g} \times \mathrm{hr}-1$, plotted in respect to ambiert temperature. . . . . . . . . . . . . . . . 63

5. Evaporative water loss of the red-breasted nuthatch in $\mathrm{mg} / \mathrm{g} \times \mathrm{hr}^{-1}$, plotted in respect to amblent temperature. . 65

6. The respiratory quotient of the red-breasted nuthatch, plotted in respect to anbient temperature. . . . . . . . . 68

7. The e/p ratio for the red-breasted nuthatch, plotted in respect to ambient temperature. . . . . . . . . . . 77 


\section{INTRODUCTION}

I. Traditional and Contemporary Views of Homeothermy and Thermoreguigtio.

A. Homeothermy and Body Temperature.

1. Birds as Homeotherms.

Birds as a taxonomic group are homeothermic and keep nearly cono stant body temperatures over a wide range of ambient temperatures. At high ambient temperatures they can tolerate a small rise in body temper ature but they must all work to prevent their body temperature from rising to a lethal leve1. At low ambient temperatures, however, not al1 birds work to prevent their body temperatures from faliing to within degree or two of the ambient temperature. Pearson (1960) classified homeotherms and their responses to low temperatures into; (1) the Obligate Homeotherms which resist lowering their body temperature as long they possess energy reserves, for to drop their body temperature resuits in death, (2) the Stubborn Homeotherms which resist lowering their body temperature when their energy reserves are high, but succumb in the fave of environmental stress when their reserves are depleted and arop their body temperature to near the ambient temperature, ther raise it tack to normal when environmental conditions once again become favorable, and (3) the Indifferent Homeotherms whose body temperatures drop to within a degree or two of the ambient temperature when they sleep, but raise spontaneously to rormal when they awaken.

Birds for the most part are obligate homeotherms (Peason, 1960). Homeothermy for them, however, is expensive, since gram far gram, amorg homeotherms, birds require more fuel than mammals, for they have the highest total heat production of any animal species (Benedict, 1938; 
Brody, 1945; King and Farner, 1961; Lasiewski and Dawson, 1967). In recent years, species from the Apodidae, Caprimulgidae, Trochilidae, and Hirundinidae, have demonstrated the ability to become torpid (Earthollumi: et a‥ 1957; French and Hodges, 1959; Howe11, 1961; Huxley et al. 1939; Jaeger, 1948; Lasiewski and Thompson, 1966; Marsha11, 1955; Shellabarger et a1. 1961; Stebbins, 1957; Thorburg, 1953). These species, Iike the mammalian hibernators, fall into groups two and three of Pearson's 1960 classification. McAtee (1947) gave a review of the older records of torpidity.

2. The body-temperature body-we1ght relationship of birds.

The deep body-temperatures of birds, like those of mammals are dependent on the metabolic rate and effectiveness of the body insulaticn. The resting body-temperature of birds, unlike that of mammals, however, is related to body-weight, and a curvilinear rise in resting body-temperature is evident with decreasing body-weight for birds weighing down to $20 \mathrm{~g}$ (McNab, 1966). For birds weighing less than $20 \mathrm{~g}$, the curvilinear function fails, and the body-temperature begins to decrease with a decrease in body-weight. Figure 1 demonstrates the body-weight body-temp relationship of birds and mammals. McNab (1966) combined the Kingo Fa:atu (1961) equation for predicting the metabolic rate of birds, with the Morrison and Ryser (1951) equation for predfcting the conductance vilu: of an animal's insulation and derived a formula which produced lire representing the trend of body-temperature to body-weight in birds (Fig-..s 1). This line, though derived from relationships of metabolic te rad conductance, follows the trend of points plotted from empisically fourd body-temperatures of birds ranging in weight from 30 to $100,000 \mathrm{~g}$. Tte variable resting metabolic rate and the heat corductance of the insulati... 
permit several conclusions to be made about not only the differences in body temperatures between birds of different weights, but also the differences in body temperatures between birds and nammals of comparabie sict.

Birds have a higher total heat production than mammals of comparabie size (Benedict, 1938; Brody and Proctor, 1932; King and Farner, 1961;

Lasiewski and Dawson, 1967), and this coupled with an effective insulation gives birds a higher body temperature. McNab (1966) stated that Lasiewsiki et ․ 1. (1964) presented data which demonstrated that birds of 20 to $200 \mathrm{~g}$ had heat conductance values for their insulation of $70 \%$ less than mamma is of the same weight. Irving (1960) pointed out that the ptarmigan, which is thought to be the smallest bird suited to arctic cold by its insulation is $1 / 10$ the size of the arctic fox, which is the smallest mammal suited to arctic cold by insulation. These relationships indicate that birds of 20 to $200 \mathrm{~g}$ have a lower rate of heat loss than mammals of comparable size and this along with their higher metabolic rate gives them a higher body temperature. Birds and mammals weighing $2 \mathrm{Kg}$ and more have similar rates of heat loss, but the higher metabolic rates of the birds gccount for their higher body temperature (McNab, 1966).

The insulation of birds weighing less than $20 \mathrm{~g}$ is similar in value to the insulation of mamma ls of comparable size (McNab, 1966). The amcunt of surface area in comparison to body weight present in the very small animals of both homeothermic classes, limits the amount of insulation the animal can possess and still be able to move (Irwing, 1960; Scholandex Et al., 1950a). These small birds possess, however, a higher metabolic 
Figure 1--The relation of body temperature to weight in birds and mammis.

Line A, B represents McNab's (1966) curve for nredicting the relationship of body temperature to welght in bisis. Portion

A represents that portion fitting the empirical data. Portion

$B$ represents that portion not fitting the empiricel ata. Iine

C represents the empirical data which fails to follow the predicted values. The horizontal line $D$ represents the mamalian standard. 


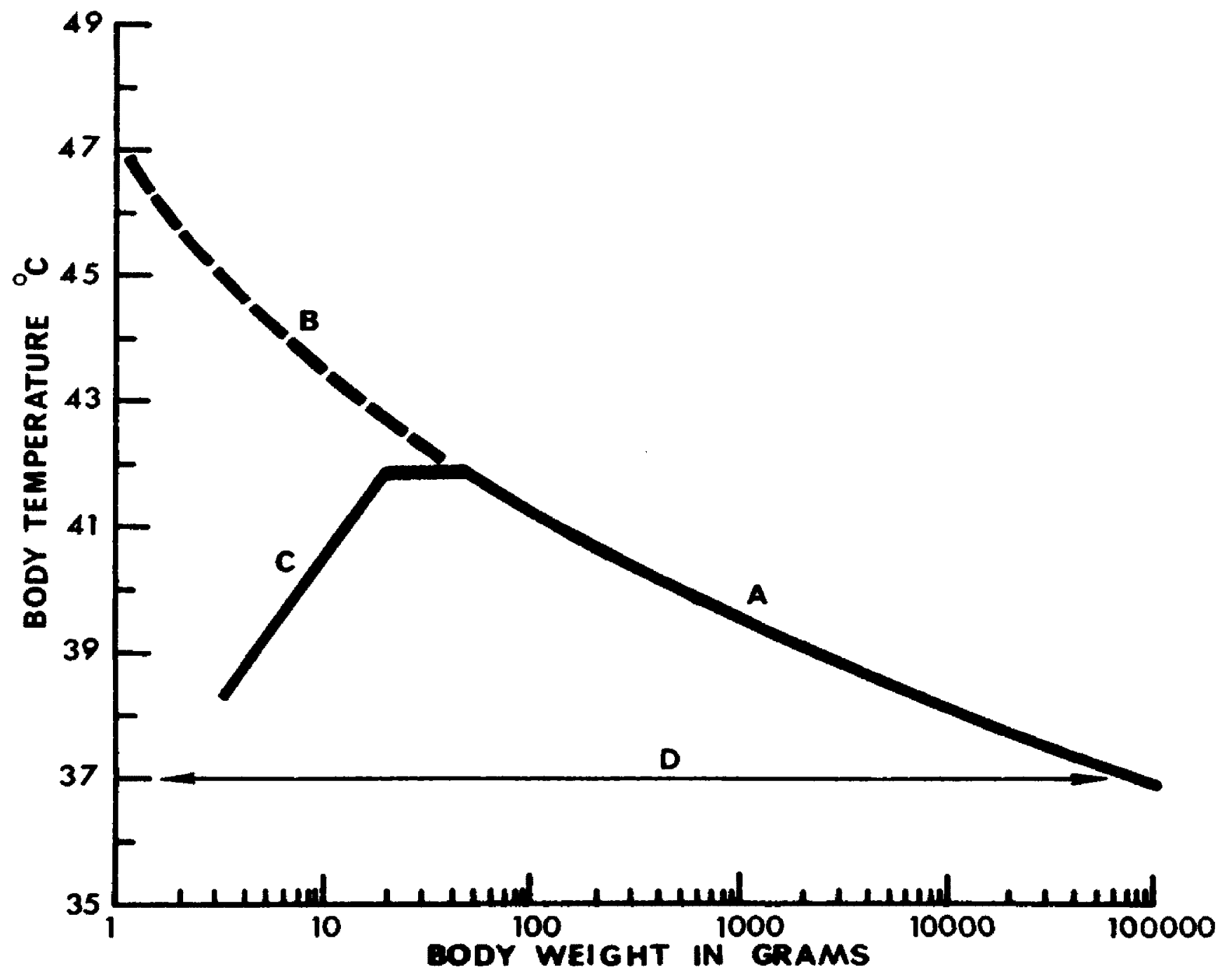


rate than comparable sized mamals which gives then higher body temperatures (McNab, 1966).

Though the metabolic rates of birds below $20 \mathrm{~g}$ are higher than those of mammals of comparable size, they are lower than the rates predicted from the King-Farner (1961) equation used by McN@b (1966) in deriving the equation of the slope of the line representing the body temperature of birds. The lower than expected metabolism, and the higher rate of heat loss due to poorer insulation, act together to lower the body temperature of these sma 11 birds from the expected values, giving a direct rather than inverse relationship between bodyweight and bodytempersture.

3. Cyclic variations in the body temperatures of birds and mammals. Wetmore (1921) studied the body temperatures of 327 species of birds from 50 families in the central United States, nd described a daily fluctuation in their temperatures, the highest being recorded durIng midday activity, and lowest during sleep. Several authors, (Baldwin and Kendeigh, 1932; Bartholomew and Cade, 1957; Bartholomew and Dawson, 1958; Dawson, 1954; Dawson, 1958; Howel1 and Bartholomew, 196la, 1961b. 1962; Irving, 1955, 1960; Irving and Krog, 1954, 1956; Kendeigh, 1934; Lasiewski, 1964; Morrison, 1962; Veghte, 1964) have since damonstrated a diurnal cycle in arctic-to-tropical birds. Fiuctutions in body temper ture in response to high and low ambient temperature have been experimentaly produced in several species by several authors, and though the cycle is related to the ambient temperature it does not wry more than few degrees, unless it is one of those species cepable of rorpor (Bartholomew et 1., 1962; Brenner, 1965; Brush, 1965; Calder, 1964; Calder and Schmidt- 
Nielsen, 1966; Farner, 1956; Hart, 1962b; Howeli and Bartholomew, 1959: King, 1964; Lasiewski and Dawson, 1964; Misch, 1960; Veghte and Herreid, 1965; West and Hart, 1966). Cylic variations in the body temperatures of small mammals in relation to ambient temperatures were found on an experimental, seasonal, and daily basis by several authors (Bartholonew and Ma: Millen, 1961; Bartholomew et al. 1964; Hock, 1951; Hudson, 1964, 1965; Hudson and Rumme1, 1966; Irving and Krog, 1954; Krog et 1. 1955; Leitnst, 1966; MacMillen, 1965). Irving (1955) stated the daily fluctuation in the body temperature of birds may be as much as $6^{\circ} \mathrm{C}$, and he recognizes three levels within the range of fluctuation; (1) the sleeping level, (2) the awake but resting level, and (3) the awake and active level. Wetmore (1921: recognized that taxonomically related species of birds often had similar or the same average body temperatures. Irving and Krog (1954) feel that the body temperature is a characteristic of each bird species, and have found little difference if any in the average resting body temperature of species from different latitudes, making the average body temperature a constant and not a variable or an adaptation to climate. Wetmore (1921) considered a seasonal variation in average body temper ture unlikely and wrote "I am, in the light of the records available ot present, unable to recognize any constant difference between body temperatures made in the same species at seasons of marked heat or cold".

\section{B. Thermoregulation.}

1. The logistics of thermoregulation.

Irving (1960) stated, "Body temperatures of homeothermic species are phylogenetically differentiated, but the differentigtion shows no 
common regard for geographical range, and their temperatures are more stable than the climates of the earth, which have changed appreciably, while the temperatures of the birds that inhabit them have apparent ly remained fixed". One of the most apparent problems facing birds of every climate is that of maintaining their deep body temperature over that range of ambient temperatures afforded them by their environment. The search for those "adaptations" or modes of "acclimatization" that have allowed them to do this, as they spread to, and inhabited every climate on earth, has become, for the physiologist, the study of "Avian Thermoregulation".

a. The adjustment of heat gein and heat loss.

Over any range of ambient temperatures the control of the body temperature depends upon the rate of heat gain and the rate of heat loss from the body. If the heat capacity and temperature of a body are constant, the rate of heat loss will equal the rate of heat gain (Kleiber, 1961 ). The heat capacity of a homogeneous body is equal to the product of its specific heat times its mass, which means its heat capacity is equal to the quantity of heat in calories, that body gains or loses when its temperature is changed $10 \mathrm{C}$ (Semat, 1962). The heat capacity of a heterogeneous body, such as an animal, is equal to the sum of the heat capacities of all its parts. Kleiber (1961) gives a formula for estimatirg the heat capacity of an animal body as:

Heat Capacity $=\left(1.0 \mathrm{Cal} / \mathrm{g}^{\circ} \mathrm{C}\right)\left(\mathrm{Kg}\right.$ of $\left.\mathrm{H}_{2} \mathrm{O}\right)+\left(0.4 \mathrm{Ca} / / \mathrm{g}^{\circ} \mathrm{C}\right.$ ) ( $\mathrm{Kg}$ dry animal matter) where $1.0 \mathrm{Cal} / \mathrm{g}{ }^{\circ} \mathrm{C}$ is the specific heat of water and $0.4 \mathrm{Ca} 1 / \mathrm{g}^{\circ} \mathrm{C}$ is the specific heat of dry animal matter. Homeotherms possess a rate of minimal oxidative heat production, known as the basal 
common regard for geographical range, and their temperatures are more stable than the climates of the earth, which have changed appreciably, while the temperatures of the birds that inhabit them have apparently remained fixed". One of the most apparent problems facing birds of every climate is that of maintaining their deep body tempersture over that range of ambient temperatures afforded them by their environment. The search for those "adaptations" or modes of "acclimatization" that have allowed them to do this, as they spread to, and inhabited every climate on earth, has become, for the physiologist, the study of "Avian Thermoregulation".

a. The ad justment of heat gain and heat loss.

Over any range of ambient temperatures the control of the body temperature depends upon the rate of heat gain and the rate of heat loss from the body. If the heat capacity and temperature of a body are constant, the rate of heat loss will equal the rate of heat gain (Kleiber, 1961). The heat capacity of a homogeneous body is equal to the product of its specific heat times its mass, which means its heat capacity is equal to the quantity of heat in calories, that body gains or loses when its temperature is changed $1^{\circ} \mathrm{C}$ (Semat, 1962). The heat capacity of a heterogeneous body, such as an animal, is equal to the sum of the heat capacities of all its parts. Kleiber (1961) gives a formula for estimatira the heat capacity of an animal body as:

Heat Capacity $=\left(1.0 \mathrm{Cal} / \mathrm{g}^{\circ} \mathrm{C}\right)\left(\mathrm{Kg}\right.$ of $\left.\mathrm{H}_{2} \mathrm{O}\right)+\left(0.4 \mathrm{Ca} / \mathrm{g} \mathrm{OC}_{\mathrm{C}}\right.$ (Kg dry animal matter) where $1.0 \mathrm{Cal} / \mathrm{g}{ }^{\circ} \mathrm{C}$ is the specific heat of water and $0.4 \mathrm{Cal} / \mathrm{g}^{\circ} \mathrm{C}$ is the specific heat of dry animal matter. Homeotherms possess a rate of minimal oxidative heat production, known as the basal 
thermostatically via its insulation, metabolism, muscular activity, and ability to refrigerate. This allows it to operate at nearly the same internal temperature over a wide range of ambient temperatures.

b. Seasonal and climatic thermoregulation.

The mechanisms controlling heat loss and heat gain in homeotherms can be altered, by either exposure for long periods at different temperatures in the laboratory, or by exposure in the wild to seasonal temper= ature changes. Edholm (1961) outlined Hart's three categories and definitions of these alterations as follows: (1) Acclimation describes alterations in an animal's reaction to a thermal condition when temperature is the only variable, (2) Acclimatization describes the alterations in an animal's reaction to a thermal condition as a result of climatic exposure (season, latitude, photoperiod, and temperature), and (3) Adaptation describes racial or species differences due to climate. The alterations produced are measurable through changes occurring in metabolic activity, effective insulation, heart rate, respiration rate, muscular activity (shivering), organ activity and weight, and body weight. Indirect metabolic measurements are relatively easy to perform, and if controlled properly, yield information about the expenditure of energy at different temperatures, the relative effectiveness of the total insulation, the nature of the material providing the energy, and the effectiveness of the apparatus for evaporative cooling. Because of the quantity and various types of data available from metabolic measurements, the science of animal calorimetry has become a valuble and popular tool for workers in thermoregulation as a means of assessing an animal's thermal restrictions. 
2. Calorimetry of the body hegt of homeotherms.

a. The historical development of indirect calorimetry.

Measuring the quantity of heat lost from the body (direct calorimetry) is difficult, but calculating the quantity of heat produced (indirect calorimetry) by measuring the respiratory exchange of $\mathrm{CO}_{2}$ and $\mathrm{O}_{2}$ is relatimely easy. Lavoisier and LaPlace (1790; from Kleiber, 1961) deduced the major quantity of heat produced by the body was due to the combination of the inspired $\mathrm{O}_{2}$ with the $\mathrm{C}$ from the metabolites to form the $\mathrm{CO}_{2}$ of expiration. Leibeg (1842; from Lusk, 1919) concluded the heat production of the body resulted from the combustion of proteins, carbohydrates, and fats, but erroneously assumed that oxygen caused this combustion. In 1852, Bidder and Schmidt (from Lusk, 1919) stated "almost all the nitrogen of protein and collagen is split from its combustion and carries with it enough carbon, hydrogen, and oxygen to form urea; the remaining part, containing $5 / 6$ of the total heat value of the protein, undergoes oxidation to $\mathrm{CO}_{2}$ and $\mathrm{H}_{2} \mathrm{O}$, which are eliminated in the respiration, the calorifacient function being fulfilied". This concept of protein catabolism was not considered valid, however, until Carl V. Voit (1857; from Lusk, 1919) proved its validity with an experiment in which he fed dogs a protein diet that contained a known quantity of nitrogen, and later recovered that same amount of nitrogen from their urine and faces. He experiments led to the concept of "nitrogen balance".

Fettenkoffes ard Voit (1866; from Lusk, 1919) calculated the grams of protein and fat catabolised by fasting mari, by measuring the grams of nitrogen in his urine and the grams of carbon in his expired air. The heats of combustion of protein and fat as found in bomb calorimeter 
were then applied directly to these calculated weights, to determine the total heat produced. Rubner (1885; from Lusk, 1919) found their determination in error, because they had failed to subtract the value for the heat of combustion of the urinary nitrogen (urea), from the heat of combustion of the protein. He concluded this was absolutely necessary since the urea represented the incomplete oxidation of protein in the body. In later studies Rubner confirmed thet carbohydrates and fats are completely oxidized in the body and in 1894 (from DuBois, 1936) wrote that he could express organic heat production as the heat of combustion of catabolized compounds minus the heat of combustion of urinary components. b. The raspirstory guotient.

ising Avogadro's hypothesis, some early investigators compared the volime of $\mathrm{CO}_{2}$ produced to the volume of $\mathrm{O}_{2}$ consumed by an animal during a metabolic trial. Regnault and Reist (1849, from Lusk, 1919) fed different mammals combinations of foodstuffs, and then measured and compared the volumes of $\mathrm{CO}_{2}$ expired to the volumes of $\mathrm{O}_{2}$ consumed after each feeding. They found the ratio of the volumes varied rot from species to species, but rather from foodstuff to foodstuff. Ffluriger (1877; from Iusk, 1919) called this ratio the respiratory quotiert

$$
\text { (R.Q. }=\mathrm{CO}_{2} / \mathrm{O}_{2}
$$

Molecules of carbohydrate, fat, and protein each contain different ratios of the elements carbon, hydrogen, and oxygen in their chemical structures. In the catabolism of these molecules, catalytic enzymes are used as a substrate for their oxidgtion. Only carbohydrates and fats, however, are completeig oxidized to $\mathrm{CO}_{2}$ and $\mathbb{H}_{2} \mathrm{O}$, while protein oxidation is incomplete; small pazt of the protein molesulesbeing con- 
verted to urea rather than $\mathrm{CO}_{2}$ and $\mathrm{H}_{2} \mathrm{O}$. An examination of a molecule of each foodstuff shows why different quantities of $\mathrm{O}_{2}$ are consumed, and $\mathrm{CO}_{2}$ produced in the catabolism of each.

(1). Carbohydrate Iespiratory guotient.

Glucose $\left(\mathrm{C}_{6} \mathrm{H}_{10} \mathrm{O}_{5}\right)$, the major molecule of carbohydrate catabolism, contains 2.1 ratio of hydrogen and oxygen. This allows the formation of $\mathrm{H}_{2} \mathrm{O}$ without extra-molecular $\mathrm{O}_{2}$ duriag catabolism. Oriy the carbon requires extra molecular $\mathrm{O}_{2}$ for $\mathrm{CO}_{2}$ formation. For each molecule of $\mathrm{O}_{2}$ consumed in the reaction, one molecule of $\mathrm{CO}_{2}$ will be formed, giving carbohydrates and respiratozy quotient of 1.0 (DuBois, 1936).

(2). Frotein respiratory guotient.

Proteins, because they are incompletely catabolised, require complicated machematics for calculacing their respiratory quotient. Lowey (1911; from Lusk, 1919) computed the respiratory quotient for the catabolism of $100 \mathrm{~g}$ of meat protein. His calculations show that after the formation of the organic nitrogen compounds and the depletion of the molecular $\mathrm{O}_{2}$, c. and $\mathrm{H}$ both remain, but $\mathrm{C}$ in the gratest quatity. Extro mojarar $\mathrm{O}_{2}$ is required to complete their oxidation. Thus the ratio of $\mathrm{CO}_{2}$ formed to $\mathrm{O}_{2}$ consumed becomes less than 1.0 . Zowey calcuided an respiratory quotient of 0.801 for the catabolism of protein.

(3). Fat respiretory quotient.

Mobilization of fat for catabolism occurs when caloric expenditure exceess caloric intake, ad involwes the hydrolysis of triglycerides to ftee fatty acids and glycerol, which are then catabolised for energy (Masoro, 1966). 5r: which give fats their characteristie sepirgtory quotients. The molecule contains very little $O_{2}$ and arter its depletion during stabolism, both 
$C$ and $\mathrm{H}$ remair. As in proteins, therefors, the ratio of $\mathrm{C}_{2}$ produced, to extramolecular $\mathrm{O}_{2}$ consumed will be below 1.0 , but because the ratio of $\mathrm{H}$ to $C$ is greater in fats than in proteins, the respiratory quotients of fats are, lower than those of protein. One mole of tripalmitin requires 72.5 moles of $O$ for its oxidation, and produces 51 moles of $\mathrm{CO}_{2}$, which results in an respiratory quotient of 0.703 (DuBois, 1936).

3. The calculacion of heet production by indirsct colorimetry.

To calculate heat production directy from the respiratory exchange, the heat equivalent of the $\mathrm{O}_{2}$ required for the combustion of each foodstuff must be known. Because the nitrogen in protein is incompletely oxidized, its contribution to total heat production is calculated from urinary nitrogen, and those volumes of $\mathrm{CO}_{2}$ and $\mathrm{O}_{2}$ involved in its catabolism are calculated and subtracted from the respiratory exchange. This leaves a ratio of $\mathrm{CO}_{2} / \mathrm{O}_{2}$ known as the non-protein respiratory quotient, from which the heat contributed by oxidation of fat or carbohydrate, or a combination of the two, can be calculated. From borb corimetric measurements of known nasses of either carbohydrete or fot, the heat produced upor combustion of either food can be determined, and from the calculations of respiretory quotient, the quantity of exra mesuine $c_{2}$ requirsd for the combustion of either can be determired. By combining the results of these two measurements, the heat equivalent of the volume of $\mathrm{O}_{2}$ involved in the combustion of either foodstuff can be calculated. Siace the non-protein respiratory quotient valuea which foll tetwesn 0.703 and 1.0 represent sombinations of fat and cabohydrate catsolism, the per cant of hest contributed by ench to the total now protein catabolism can be calculated.

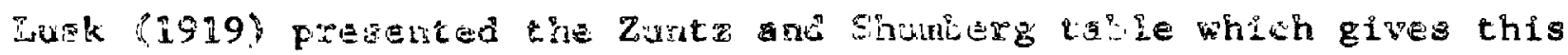


information, as well as the caloric equivaleat of a liter of $\mathrm{O}_{2}$ t any non-protein respiratory quotient (DuBois, 1936).

Masmu-Levy (1901; from DuBois, 1936) determined that in man who had fasted 12 to 14 tours, protein furnished 12 to $18 \%$ of the total calories. He made a table of caloric values for oxygen, based on this knowledge, which enabled experimentors to caleulate total heat production from the total respiratory quotient, and thus groid the collection and analysis of urine. Many investigators began employing caloric value of 4.8 Cal/1 to the osygen consumed by individuals who had fasted for about 14 hours, and who had a total respiratory quotient of pproximately 0.82 (DuBois, 1936). The practice of measuring only the cxygen consumption soon developed, and number of varied and specialiged apparatuses were developed, the descriptions of which can be found in Rusk (1919), DuBois (1936), Brody (1945), and Kleiber (1961).

4. The role of the respiratory quotient in indirect calorimetric measurements. a Finding the caloric equivalent of oxygen for birds.

The procedures of indirect calorimetry have been applied to studies of avian metabolism, and the practice of omiteing measurements of urinary nitrogen, and using the total respiratory quotient for determining the caloric palue of the oxygen consumed have followed (King, 1957). Barott and Fringle (1941) experimented with chickens, and found the caloric equivalents for oxygen, as given in the Zuncz and Schumberg table applicable to their aimals when they had a respiratory quotienc of bout 0.70 . Henry et al. (1934) concluded from the basis of their experiments that Indirect calorimetry is not a proper technique to use in determining the hest production of birds because the callic equivients for the oxymen 
consumed when the bird has a respiratory quotient below 0.71 are not available. Mellen and Hill (1955) suggested the metabolic rate of birds be given only in terms of oxygen consumption and not heat production. King (1957) stated, however, that ". . Even though the validity of estimating the heat production of birds through reference to the Zuntz and Shumberg table is not unequivocally established. . . the scant evidence available suggests the method is valid".

Many recent authors (Brush, 1965; Calder, 1964; Calder and Ring, 1963; Dawson, 1958; Dawson and Tordoff, 1964; Lasiewski et al., 1966; and Lasiewski and Dawson, 1967) have used caloric value of $4.8 \mathrm{Ca} / 1$ for the oxygen consumed by bird in the resting, unrestrained, postabsorptive condition, while others (Dawson, 1954, Dawson and Tordoff, 1959; Misch, 1960; Veghte, 1964) in similar experiments have used a caloric value of $4.7 \mathrm{Ca} / 1$. Kleiber (1961) gave oxygen a caloric equivalent of $4.7 \mathrm{Cal} / \mathrm{I}$ in metabolism trials and makes no distinction as to whether the value applies to mammals or birds.

b. Respiratory quotient values below 0.71 .

Respiratory quotient values below 0.71 are apparently real, and occur regularly in avian metabolism trials, and apparently represent a difference between the fasting metabolism of birds, and of mammals (King, 1957), though Kleiber (1961) reported the occurrence of these low respiratory quotients in mammals fed special diets. In the catabolism of protein, uric acid is the product of the imeomplete combustion in birds, arid its formation from the protein molecule leaves behind quartities of carbon and hydrogen which require more excra moleculds oxygen for their complete crication than if urea were formed ga in mamals. The protein 
respiratory quotient of birds, therefore, is about 0.75 to 0.74 , rather than 0.82 as in mammals (King, 1957; Kleiber, 1961). King (1957), in contrast to Mellen and Hill (1955), felt that protein catabolism in birds cannot explain avian respiratory quotient values as low as 0.65 , and suggests instead, (1) incomplete oxidation of fat, and (2) interconversions among fat, protein, and carbohydrate as being possible sources of these low respiratory quotient values. Kleiber (1961), however, presented a reaction demonstrating the catabolism of Alanine in birds to uric acid, $\mathrm{CO}_{2}$, and $\mathrm{H}_{2} \mathrm{O}$ which gave an respiratory quotient value of 0.667 . Kleiber, (1961) also suggested that low respiratory quotient values may indicate the synthesis of carbohydrate from fats, as must happen in the lactating cow. Carbohydrate synthesis from fat is also suggested by the work of Fienry et a1., (1934) who found that blood glucose in cocks rose as their respiratory quotients fell to values below 0.71 . The caloric equivalent of the oxygen consumed by animals with respirat lry quotients of 0.70 to 0.65 is still an unsolved question.

c. Respiratory quotient values above 1.0 .

Respiratory quotients above 1.0 indicate the synthesis of fat from carbohydrate (DuBois, 1936; Kleiber, 1961; Lusk, 1919). This can be well exemplified by the rapid fat deposition shown in geese and pigs that have been force fed grain. Bleibtreu (1901; from Lusk, 1919) obtained respiratory quotients as high as 1.33 in geese stuffed with grain. The elevated respiratory quotient resulted from the formation of an $\mathrm{O}_{2}$ poor product, from an $\mathrm{O}_{2}$ rich precursor, so the $\mathrm{O}_{2}$ absorbed from the outside will be low in relation to the $\mathrm{CO}_{2}$ produced. The fat formed from a quantity of glucose will have less heat content than the glucose from 
which it was formed, hence the reaction is exothermic. For every liter of $\mathrm{CO}_{2}$ produced in the synthesis of fat, $0.8 \mathrm{Cal}$ will be released. When calculating the total heat produced in respiratory trial involving a respiratory quotient over 1.0 , that quancity of $\mathrm{CO}_{2}$ not involved in creating the respiratory quotient of 1.0 , is multiplied by this factor $(0.8 \mathrm{Ca})$ and the product is added to the other heat values (DuBois, 1936). d. The yalue of the respiratory quotient as an index of the intermediary. metabolism.

Kleiber, (1961) stated, "The respiratory quotient is inadequate as an index for the nature of the intermediary metabolism, and particularly of the precursor-product relationship". He feels, however, it is still a valuable tool in indicating the nature of the products being catabolised. Krog (1916) mentioned that the "assumption on which the deductions from respiratory quotients are usually based may not be strictly correct, because (1) substances other than carbohydrates, fats, and proteins may be catabolised, (2) synthesis may take place, (3) there may be a difference between the $\mathrm{CO}_{2}$ produced in a given time interval and the $\mathrm{CO}_{2}$ exhaled at that time". Irving et al., (1930) felt respiratory quotient values could be temporarily distorted by the retention or addition of $\mathrm{CO}_{2}$ from the large reserves the animal possesses. Kleiber (1961) proposed, therefore, that radionctive tracers be used in determining product-precursor relationships rather than respiratory quotients.

e. The effects of low ambiene temperatures on the respiratory guotient.

Kayser (1937a, 1937b) reported that absorptive animals in cold produced extra heat from lipid combustion exclusively, as indicated by their respiratory quotient. Chenier, (1954; from Nasoro, 1966), Page (1957); Page and Chenier (1953) working with white sots furchered this notion, and Page 
(1957) coneluded on the basis of regpiratory quotients that in mamals fats were preferentialiy uged for heat production upon prolonged exposure to cold. Masoro (1966) quoted other studies not using respiratory quotients as the criterion for fat catabolism, and concluded that cold-acelimated rats dis not use fot preferentially for nonshivering themeogenesis but: rather 11 food tuffs were used at an increased rate. Cold-acelimated rat:, howewer, when fasted af cold temperatures, did not develop ktosis or hepstic fat infiltration because, unlike non-cold acclimated nimals, their livers possessed a greater capacity to oxidize fat.

Scholander et al. (1950b) found no indication thet cold modified the respiratory exchinge of arctic animals, hence their respirotory quotients were uaffected by temperature. Krog et al. (1955) worked with wild brown and white laboratory rats (Rattus norvigicus) anchor ge, Alaks, and found that cold did not affect the respiratory exchange or respiratory quotient of these animals. Irving and Hart (1957), and Hart and Irving (1959) in summer and winter studies of the harbor seal (Phocg vituling) and winter studies of the harp seal (Phoca groenlandica) reported no lterations of respiratory quotient in these seals due to ither sedson or temperature. Irving et al., (1955) worked with both summer and winter individu is of the retic red fox (Vulpes vulpes alescensis), the Alaska red squirrel (Tamisciurus nudsonicus preblei), the porcupine (Erethigon doregtum myops), the black brent (Brente bernicla orientelis), and the northwestern crow (Corrgys eaurinus), and concluded that even though respiratory quotient changes occurred in the red squirre1, the porcupine, the black brant, and the worchwestern crow, these were not the result of changing season or tempereture. They concluded any variations which 


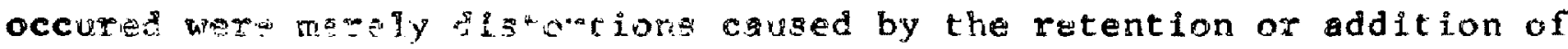

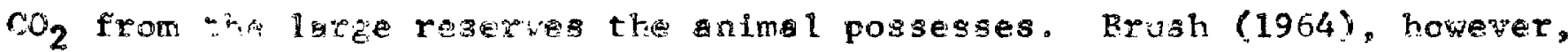
fourd sibrticent aifereretin the respiratory quotient of the Califo

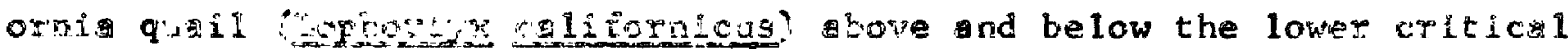

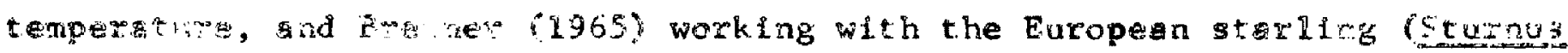
velegris found their mean respiretory quotient decreased when the ambient temperistedectsased.

5. Tnerroregulatiog gt gmbient temperatures below the body temperature. SUyer 1 rétews Cowson and Schmidt-Nie1sen, 1964; Gelineo, 1964; Herdy, 1961; Hort, 1957, 19620, 1964; Fiudson, 1962; Hudson and Eartholomew, 1964; IFYerg, 1960, 1964; KIng and Farner, 1961, 1964; Kleiber, 1964; West, 1962) treat in comprehengive way the methods employed by homeotherms to preserve their body tamperature in spite of a changing ambient temperature. From these rupis ard the studies treated in them, several terms and number of concepts hure emerged, which describe the metabolic, evaporative, and ingulative resporses of homeotherms to both high and low tempertures. a The gore of thorral reutrality, the resting metabolic rate, gnd physicgl thernoregulation.

Iy pplying varlous methods of indirect calorimetry, it has been possible to measure on anima ${ }^{\circ} \mathrm{s}$ changes in heat production in relation to changes in the ambient temperature. Since the time of Iavoisier, the hest production of arimla fos been studied, and it has been estalis hed

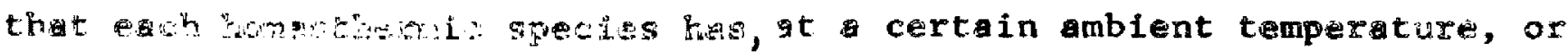
Qw (the Au of pes Ing ne 
mointain the body temper ure (Benedict, 1938; Brody, 1945; DuBois, 1936; Kleiber, 1961; Ingk, 1919). The range of ambient temperatures over which an animal can math its hody temperature via its resting metabolic rote, is disetiy setrad to the efectiveress of its insulation. Adjust-

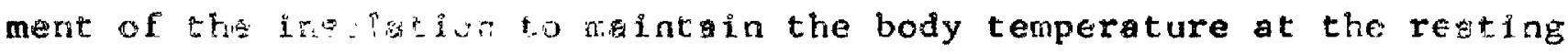

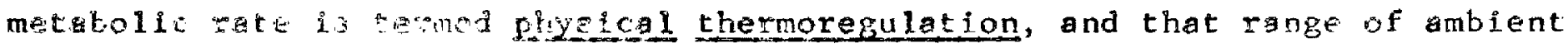
temperatures witw whict it is effective, is the zone of thermal neutrality. b. Fur ard fegters es insulation.

Insuigtion in aimals is in the forms of fur, feathers, subcutaneous fot deposits, and vaseular heat exchanges in the extremities which act to regulate the rete of total heat loss. Fur and feathers form an external substace of poor conductance between the skin surface, and the air. The total irsulative quality of fur depends upon its depth, a quality which undergoes sesonal changes in response to high and low temperatures (Hambe 1, 1955; Hart, 1956). Irving (1960) compared the feather thickriess of systematically related arctic and tropical birds, and found no difference between the two. He found, however, that the structure of the contour feathers of arctic birds allowed them to trap more ir per mass of fathers, thon the feather structure of the troplcal birds. Mammo18, by growing longer fur or shedding old fur, vary their insulation. This variation is apparent seasonally as well as climatically anong mammis. Fluffing fur wil not increase its insulative value, for as Hammel (1955) pointed out, ineresed compecive losses from fluffed fur reduces the

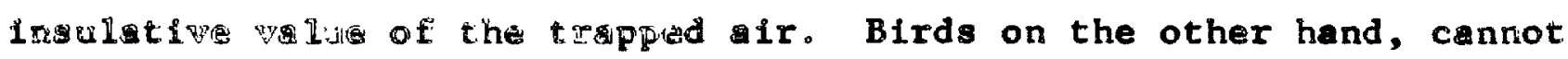
grow lower festhes witrow interfering with their flight function (ITwing, 1960) 850 goly upon the structure of their feathers to produce 
effectipe ton for increased insulation when they are inactive (Troing, 1960; Whte, 1964; Veghte and Herreid, 1965; West and Hart, 1966), Het dislpator through fur and feathers is facilitated by sleeking them to tho buly, we through other physiological or behavioral means (Irving, 1960)。 the feabers of $\mathrm{f}$ irds may be important in preventing rapid radiative gains from the eavironment. Whus, an animal's fur or feethers, gives it a flexible system for segloting the flow of heat from its body.

c. The use of the extemities in controlling heat exchange.

The apperage of many birds and mammals are poorly insulated, and the tissue there often experience a range of temperature fluctuations never toleratef or prienced by deep body tissues. Claude Bernard in 1876 (from Irvitig gro Krog, 1955) called attention to the heat conserving possiblitieg of vilus irvesting arteries passing to the surface, and anatomists howe thed this possibility for years. Bazet et el. Bazet et 1 . (1948) have demonstrated the presence of a temperature gradlent ruanteg aistoly in the large artery and vein concomitant in the appendages of man, indfcating the presence of a counter-current heat exchanger mechenism. Scholanist (1955) mentioned the work of many researchers who demongtrated arceriowenous retes, which act as heat exchangers in the extremitis of mory alnals and stated these may be interpreted as being

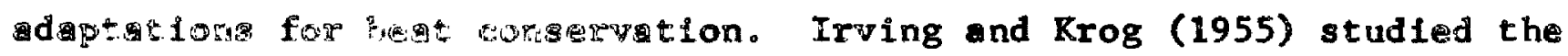
occurrance of tomperste gradient along the appendages of severgl mamuls, gid glaumb-wired guil (Larus glaucescens) and found, "CoolIng of the * isus witin thick insulation and before they are exposed to cold indirge that the hegt of arterial blood returns to the veins 
rather than escoping to the air ${ }^{* 0}$, and the occurrence of sharp skin temperature gradexts in the thickly insulated portion of an appendage ". . is good evidence tive the conservation of heat of arterial blood by means of

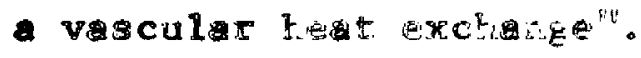

Mary Muthor tegrolomew et al. 1953; Chatfield et al. 1953; HoweII ard Imetholoww, 1961a, 1961b; Irving, 1960, 1962, 1964; Irving and Krog, 1955; Zutre 2f. 1962; Johansen, 1961; Kah1, 1963; Scholander,

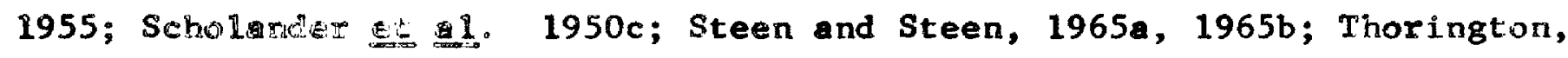
1966) have recently described the use of the extremities for heat conservation. Goling the extremithes to reduce the rate of heat loss from them can be accomplished ty reducing the flow of blood to them. This is an especialy importint function for animals that are resting in cold air, on snow, or $1 \mathrm{n}$ ig wer, for if their extremities were kept at the same temperature sheir bodiss, the rate of heat loss from them would overbalance their métolic he gain and severe hypothermia would goon result. The use of the extremities as avenues of heat 1oss, to prevent overheating of the arimal during activiey or severe insolation is another function of this vascular hear ackanger system. By increasing the blood flow to the extremities and roish their temperature above that of the air or water around them, gregt quntiles of heat can be lost through them.

Irying e: 2. (1956) worked with swine, and Irving and Hart (1957) and Hart rod Erwatue 1959 . worked with harbor seals, and found in these animals, the cowing of their skin for heat conservation in response to

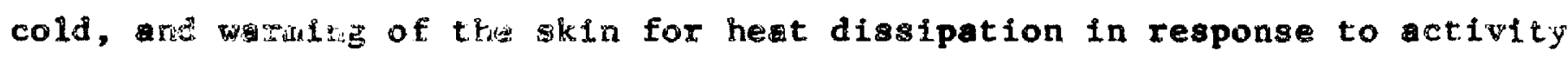
or high mbitit tomperatures, gave these animals as effective on insulaton if they we cowered with thick insulating fur. The cooling 
of the skin in these animals produces a temperature gradient through the underlying subcutaneous fat, which like the temperature gradients of the extremities is the result of vascular adjustments which act as modified heat exchangers. The ability of the skin and fat of these short haired mammals, and the tissies of the poorly insulated extremities to vary between a heterothermous and homeothermous condition, as regulated by vascular modifications, allows these tissues to function effectively as a flexible form of insulation to ald the animal in conserving or dissipating heat (Irving and Krog, 1955; Irving, 1964).

d. Chemical thermoregulation.

The heat-retairing qualities of an animal's total insulation: reaches maximum at the low end of the zone of thermal neutrality. If the ambient temperature is lowered beyond the end of the zone of thermal neutrality, heat is lost through the insulation faster than it can be gained from the resting metabolic rate, and to maintain the body temperature heat gain must be increased by elevating metabolic heat production. Hardy (1961) expressed the efficiency of the increased heat production at low ambient temperatures as that percentage of the increased heat which is stored in the body. Expressed mathematically this states that:

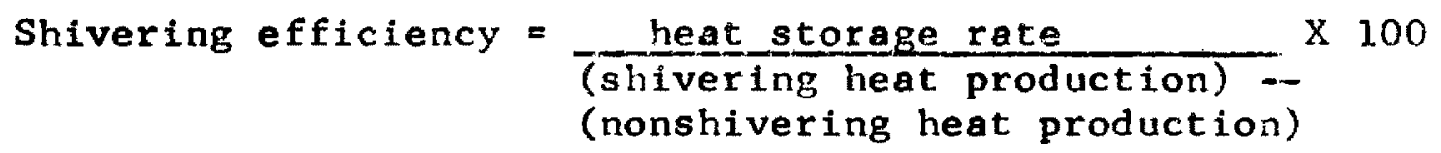

In mammals, the firat activity responsible for elevating the metabolic rate during short-term exposure to cold is shivering (Hemingway, 1963). Activity will also elevate the metabolic rate, but because of the quantity of heat lost via convection, due to movements, the percentage stored is 
less than if the arimal were standing st11l and shivering (Hardy, 1961 ). After long-term exposure to cold, many mamals are able to elevate their metabolic rate without shivering, a process which has been termed nonshivering themmogensis (Fardy, 1961; Hemingway, 1963; Masoro, 1966 ). Sellers et al. (1954) experimentally established the concept of nonshivering thermogensis, and since that time several others (Cottle and Car1son, 1956; Davis, 1960; Depocas et a1., 1957; Hart et a1., 1956) have furthered and added experiment 1 support to the concept. The phenomenon of nonshivering thermogensis has been the subject of a great deal of research in recent years and is thought to be under the control of adrenal meduliary hormones. Edholm (1961) considers the concept of nonshivering thermogensis as being one of the most important findings of heat production studies in years, even though it seems restricted to small, or poorly Insulated mamma 18 .

Hart (1963), and Chaffee et a1. (1963) were not able to induce a nonshivering thermogenic response from cold adapted birds injected with noradrenalin. Steen and Enger (1957), West (1962; 1965), have found shivering to be the major source of heat production in wild birds. Chaffee and Mayhew (1964) have lent support via biochemical methods to the theory of Steen and Enger (1957) that shivering in the pectoral muscles is the birds major method of increasing thermogenesis in response to cold.

Experiments by West $(1962,1965)$ indicated that the intensity of shivering in the pectoral muscles increased as the ambient temperature fe11, and that the pateern of this shivering was unaffected by season, 
or length of exposure to cold. It appears, therefore, that birds probably cannot elevate their metabolic rate without shivering. West (1965) concluded that most smal1 temperate, sub-arctic, and arctic birds must shiver when inactive at most of the ambient temperatures they encounter.

Freeman (1966) found, in agreement with Randa11 (1943) that the day-old chick, (Galins domesticus), exhibits homeothermic control at moderate ambient temperatures $\left(25^{\circ} \mathrm{C}\right.$ to $\left.26^{\circ} \mathrm{C}\right)$ with little or no evlderce of shivering. Randall (1943) stated that even though shivering oceured in young chicks after the first day, it was not effective in preventing the body temperature from dropping slightly, upon exposure to room temperature, until the seventh day and incapable of preventing hypothermia at ambient temperatures below $20^{\circ} \mathrm{C}$ until the down feathers were replaced with the adult plumage. Though Freeman (1966) postulated the presence of nonshiver ing thermogensis in the day-old fowl, he was unable to produce the nonshivering thermogenic response in them with either adrenalin or noradrenalin Injectlons. Baldwin and Kendeigh (1932), Dawson and Evans, (1957, 1960), and Kendeigh (1939) found that the nestlings of altricial species are essentially poikiliothermic in their response to low ambient temperatures until the muscular and nervous mechanisms controlling heat pro-

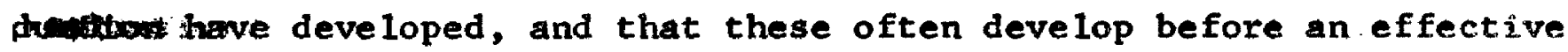
insulative plumage does. Dawson and Evans (1957, 1960), Kendeigh (1939), and Odun (1942) also found in some altriclal species that muscle tremors occurred inversely in relation to fluctuating ambient temperatures at the same time their metabolic rates began showing homeothermic response. Though no data, so fac, has eatablished the presence of nonshivering 
thermogenesis in birds, more species need to be examined before we can say it does not exist ia them. The elevation of the metabolic rate via increased muscle tone, shivering, or nonshivering thermogenesis is termed chemical thermoregulation.

6. Graphical representation of thermoregulation at ambient tergeretyres. below the body temperature.

a. The Newtonian model.

The classical method of representing the increase in metabolism due to chemical thermoregulation is to fit a linear regression to tho metabolism values as they increase at a series of ambient temperatures below the zone of thermal neutrality. The regression line, if extrapolated to zero metabolism, should cross the abscissa at value within the animal's norma 1 range of body temperatures (Hart, 1957; Scholander et a1, 1950b; Steen, 1958; West, 1962). By this method, that ambient temperiture where physical thermoregultion gives way to chemical thermoregulation is represented by point where a horizontal line representing the zone of thexmal neutrality crosses the regression line of increasing metabolism. This point, known as the lower critical temperature, represents that point at which the animals insulation has reached its maximum. Scholander et al. (1950b) proposed this method of representation and figure 2 illustrates these principles, with the metabolic rate being plotted on the ordiate and the ambient temperature being plotted on the abscissa.

The slope of the line representing the increase in metsbolic rate is less steep in those animals possessing wide zone of therms 1 neutrality then ir those with a short zone of thermel neutrality (Kleiber, 1961). This fact erables lis to exaluate the efficiency of the inguidion 
between species by comparing not only the slope of the lines indicating the metabolic increase, but also the width of the zone of thermal neutrality. According to Scholander et a1. 1950b), the critical temperature gradient (ヘTC), is the difference between the body temperature and the ambient temperature at the lower critical temperature, and is by definition the greatest temperature gradient over which physical thermoregualtion is effective. The $\triangle \mathrm{TC}$, therefore, is dependent on the efficiency of the total insulation, and the value of the total insulation can be calculated from the following equation:

$$
I=\Delta \mathrm{TC} / \mathrm{E}
$$

which is a modification of Newton's law of cooling where I is the total insulation, $\triangle \mathrm{TC}$ is the critical thermal gradient at the lower critical temperature, and $\mathrm{E}$ is the metabolic rate. The inverse of insulation is conductance and the efficiency of an animal's insulation can be determined by calculating its conductance value from the following equation:

$$
C=E / \Delta T C
$$

where $C$ is the conductance, and $E$ and $\triangle T C$ are as above.

Scholander et a1. (1950b) expressed conductance as the slope of the line representing the Increasing metabolic rate and Lasiewski (1963) presented this idea graphically. This method does not require the determination of a lower critical temperature or a zone of thermal neutrality for its representation of insulation. In much of the literature on smal1 birds and mamma1s, the effectiveness of the Insulation is expessed as total insulaw tion or conductance. 
b. Chemical and physical acclimatization:

Applying the principles of Scholander's Newtonian model, Hart (1957) graphed the classical picture of physical and chemical regulation and the changes which acclimatization can cause in either to provide an animal a means of surviving prolonged exposure to cold (Figure, 2b). By increasing the insulation the lower critical temperature is lowered, the zone of thermal neutrality extended, and the slope of the regression line representing chemical thermoregulation lessened to allow the lower limit of survival to be extended several degrees lower without changing the animals metabolic capabilities. If the insulation remains constant, the extention of the lover limit of survival can occur only through an extention of metabolic abilities, which means extending the original line of metabollc increase to even greater rates to cover the heat lost at the lower temperatures. This model, like Scholander et al.'s (1950b), uses a single ambient temperature as the lower critical temperature.

c. West's model of acclimatization for small birds.

In their work with small birds, Dawson (1958), Dawson and Tordoff (1959), and King and Farner (1961), suggested that the lower critical temperature was not a single well-defined point for these animals as defined by the Newtonian model, but rather that an increase in chemical regulation would preclude the attainment of maximum physical regulation, and gradual rather than abrupt increase in metabolism would occur. Dawson (1958) mentioned 180 that gradual rather than an abrupt change in metabolism occured in some of the examples used by Scholander et 1 . 
(1950b) in their proposal of the Newtonian mode1, and suggested that in some species of small homeotherms the lower critical temperature is an abstraction, though still useful from theoretical stand-point. From the data of several workers, West (1962) calculated the insulation index:

$$
I=\Delta \mathrm{TC} / \mathrm{E}
$$

for several small birds over a range of several degrees ambient temperature. He found their total insulation increased for several degrees below the supposed zone of thermal neutrality reaching a maximum in a curvilinear fashion. He also agreed with the above workers that the increage in metabolic rate was gradual rather than abrupt in small birds, and sug. gested that no real zone of thermal meutrality or lower critical temperature could be described for these small animals. From these observations, West (1962) constructed graphic model (see Figure 2c) which demonstrated the gradual increase of both the total insulation and metabolism. Where metabolism alone functioned, the slope of the curve at the lower ambient temp. eratures extrapolated to the body temperature as in the Newtonian model. At higher timperatures where insulative and metabolic mechanisms work together the slope extrapolated beyond the body temperature. He concluded that definite lower critical temperature and prolonged zone of thermel neutrality probably do not exist for small wild birds. Several studies of severel other species of small birds have agreed closely with West ${ }^{\circ}$ mode1 (Dawgon and Tordoff, 1964: Hart, 1962b; Lasiewski and Dassom, 196ik: King, 1964; Lasiewsk1 et 1., 1964; Veghte, 1964; Veghte and HerTeid, 1965; West, 1965; West nd Hart, 1966). The California qual (Lophorty. colifornicus), bird considerably larger than those fitting West ${ }^{\circ}$ (1962) model did conform to the biological application of Newton ${ }^{\circ}$ Law of Coolinit 
Figure 2-Mndels of metabolic and Isulative thermoregulation.

(2) The Newtonian model of metabolic and insulative thermoregulation illustrating graphically the zone of themal neutrality (ZTN) where physical thermoregulation occurs; the lower critical temperature (LCI) where the insulation reaches it maximum and physical regulation gives way to chemical regulation; and the upper critical temperature (UCT) where the animal begins to actively cool via evaporative water loss. Heat production (MP) is plotted on the ordinate, and ambient temperature $\left(\mathrm{T}^{\circ}{ }^{\circ} \mathrm{C}\right)$ is plotted on the bocissa.

(b) Hart's (1957) model of metabolic vs. Insulative acclimatization. Wine $A, B$ represents the zone of thermal neutrality, and line $A, B, B I$ is the extention of the zone of thermal neutrality as the result of insulative acclimatization. Ine $B$, $C$ represents the incresse in metabolism above the lower critical temperature at point $B$. Line $C$, $D$ represents the incressed metabolic capability for an animal which has undergone metabolic acclimatization. This increased metabolic ability has moved the lower lethal temperature from $L_{1}$ to $I_{2}$. Line $\mathrm{B}^{1}, \mathrm{C}^{1}, \mathrm{D}^{1}$ represents the decreased metabolic slope: required to extend the lower lethal temperature from $I_{1}$ to $I_{2}$ when insulative rother than metabolic acclimatization occurs. Heat production (HP) is plotted on the ordinate, and ambient temperature ( $\mathrm{TaOC}$ ) is plotted on the abcissa.

(c) West's (1962) model of metabolic and insulative thermoregulation. In this model no zones of thermal neutrality, upper critical temperature, or lower critical temperature are evident and the metabolic rate (solid line) has a curvilinear relationship. In this scheme the insulation (heavy dashed line) increases slowly over aide range of ambient temperatures. The slope of the line representing an increase in metabolism within the influence of the in creasing insulation, does not extrapolate to zero metabolism at a point within the range of normal body temperatures but rather to an unpedicted point above the body temperature. That portion of the line representing chemical regulation lone (light dashed Iine), however, does extrapolate to the body temper ture as prescribed by the Newtonian Model. Heat production in \% (MP\%) is on the left ordinate, insulative increase in $\%(1 \mathrm{i} \%)$ is on the right ordinate and, the amblent temperature $\left(T{ }^{\circ} \mathrm{C}\right)$ is on the sbicissa. 


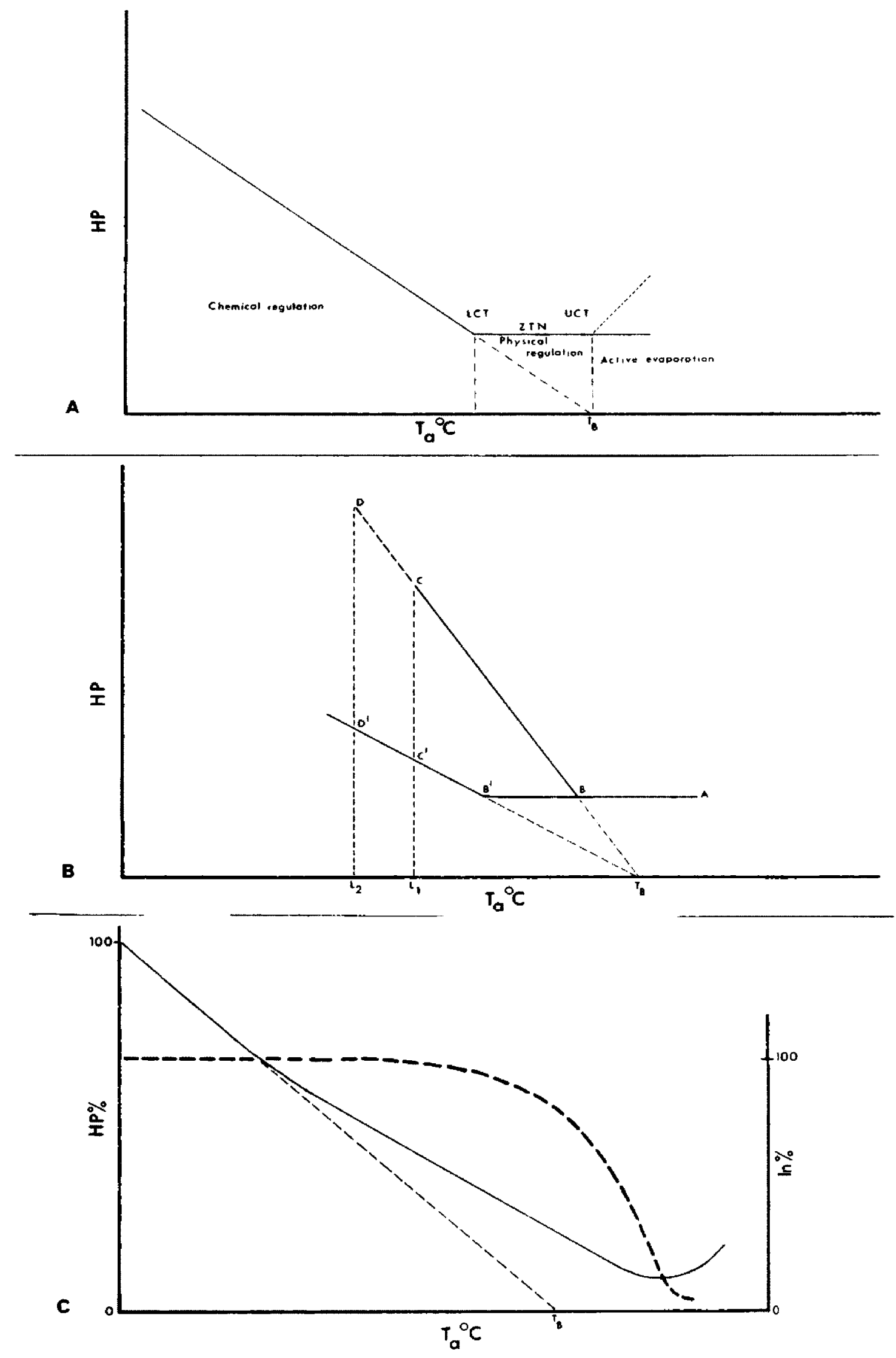


and showed a distinct zore of thermal neutrality and lower critical temperature (Brush, 1965).

d. The velidity of Newton's Law of Cooling As applied to homeotherms.

The chemical and insulative regulation models of Hart (1957) and West (1962) predicted that the slope of the line representing chemical regulation alone would extrapolate to the body temperature in agreement with Newton's Law of Cooling. It is interesting to note, however, that a great deal of varialify on this point has occured throughout the liter ature on gmall birds and mammals. Verious investigators working with birds (Exott and Pringle, 1946; Cade et el, 1965; Dawson, 1954, 1958; Hart, 1962b; Kendeigh, 1944; Misch, 1960; Salt, 1952; Steen, 1958; Wa11gren, 1954), and others working with mammals (Bartholomew and MacMillen, 1961; Bartholomew et 1 . 1964; Hart and Irving, 1959; Irving et 1 , 1956; IrvLrg and Fart, 1957), found that the slope of the line representing chemical regulgtion did not extrapolate back to the abscissa t value within the normal range of body temperature but rather to an unpedicted walue. King (1964) believed it fortuitous that his regression line for the meta* bolic increase in white-crowned sparrows (Zonotrichia leucophrys gambelif) extrepoleted to body temperature and suggested it may not have done so had the birss been armined at wider range of ambient temperatures. Data from other irvestigtions of birds (Brush, 1965; Cglder, 1964; Dawson and Tordoff, 1959, and 1964; Lasiewski, 1963; Lasiewski et 1. 1964; Lastewski and Dawson, 1964), birds and mamals, (Scholander et $1.1950 \mathrm{~b}$; nd Irving EE 21. 1955), find mema 1s, (Eartholomew et al., 1964; Hutson, 1964; Tretag et 1 1956; Krog et 1. 1955; Leitner, 1966; MacMi11en, 1965!, howerer, fit the Newtonien model firly well with the slope of the lirt 
representing chemical thermoregulation extrapolating back to within the range of normal body temperatures. Kleiber (1961) felt the Newtonian model of heat loss could not really apply to honeotherms, because Newton"s L.w refered to the loss of temperature, not to loss of heat, Kleiber (1961) stated, "It is therefore unlikely that Newton"s Law of Cooling is properly applicable to the heat loss of homeotherms where there is no decrease in temperature and therefore no cooling. The influence of body aise on the rate of temperature 1083 (cooling) is different from the influ. ence of body size on the te of heat loss (without cooling). The applica= tion of Newton ${ }^{\circ} s$ Law to the heat loss of homeotherms would imply there is no such difference". King (1964) was in general agreement with Kleiber"s opinion.

e. Thermal conductance and total insulation of smal1 birds and mammals. Using the principle that a lower critical temperature can be estimated, and expressing maximal insulation in terms of conductance, Lasiewski (1963) and Lasiewski et al. (1964) computed graph which showed that for small birds and mammals conductance increased inversely with decreasing body weight. Their graph showed that the conductance values for birds of both temperate and arctic areas are lower than those for mammals of comparable sige from the same area. This indicated that the feathers of these smaller birds were better insulators than the fur of the small mammals, which agreed with the concepts of Veghte and herreid (1965) for birds and Hammel (1955) for mamals. Misch (1960), using the Newtonian model, calculated the total insulation of several birds from the litereture as weil as the nothern blue jay (Cyanocitta cristatg tromial and from her study found the could relate, in most cases, the 
effectiveness of the insulation with the birds yearly thermal cycle. King (1964), cautioned gainst using insulation and conductance values calcul= ated from an estimated lower critical temperature for indicating more than physiological differences between animals because of the errors involved in identifying the lower critical temperature.

7. Thermoregulation at ambient temperatures above and equal to the body temperature.

a. Hypothermie vg. hyperthermis.

Baldwin and Kendeigh (1932) demonstrated that the upper lethal body temperature was the same for embryonic, neonatal, juvenile, and aduit birds, but that the lower lethal body temperature varied with age, being highest in adults; even so many adult birds, as well s neonat 1 nd juvenile birds, withstood lowering their body temperatures by $10^{\circ} \mathrm{C}$ while no age group withstood a rise in body temperature of more than $4^{\circ} \mathrm{C}$. This demonstrates not only the poikiliothermic nature of immature birds, but 1 so indicates the narrow margin which exists between the normal and upper lethal body temperature in adult and immature homeo= therms. Destruction of metabolic enzymes and other proteins within the cells occur at the upper lethal body temperature and hence heat death results from irreversable cellular destruction. Once an animal ${ }^{\circ}$ body tempar ture begins to rise, the rote of its metabolic hest gir reactions increses logarthnatically in accordace with the van ${ }^{0}$ Hoff effect $\left(9_{10}\right)$, which levites the body temperature even more. If heat gain were ilowed to contirue urcontrolled, the metatolic rate would continue to ircrease until denaturation of the enzymes at the lethal body temperatire caused 
the metabolic rete to fil off and stop (Brody, 1945).

Hypothermila without freezing, has a wider range of safety and does not destroy cells. Rapid rewarming of an animal whose body temperatuxe has been lowered several degrees will often restore it to normal with no ill effects (Burton and Edholm, 1955). Kreyberg (1949) considered that Low body temperstures, whether accompanied by freezing or not, probably do some tissue damage though he does not consider the damage irreversable and lethal in heat coagulation. Death from hypothermia in homeotherms probably results from circulatory fallure and changes in the nervous tissue from anoxia. Indifferent and stubborn homeotherms, can lower their body temperatures to levels that would be fatal to obligate homeotherms, a1. though many of the former Iso have limits below which their body temper * atures cannot be safely lowered (Kleiber, 1961).

b. Regulating the body temperature at high ambient temperatures.

An anima ${ }^{\circ} \mathrm{s}$ activity is more restricted, and his thermal boundaries more defined and limited at high environmental ambient temperatures than at low ones. Most of the reviews on thermoregulation mentioned earlier discuss problems of controlling the body temperature at high ambient tempertures, but four reviews in particular (Dawson and Schmidt-Nielson, 1964; Hudson, 1962; Fudson and Bartholomew, 1964; King and Farner, 1964) deal with the thermoregulatsry problems of homeotherms living in hot environments (1) Fesegye heet 1009.

As Inng es the ambient tempersture remains below the body tempera. ture, convection, orit ragtion can be used by the animal as avenues to gisgifere hit, but when the ambient temperature is greater than the body temperature the and gains het from his enviroment through these 
former avenues of heat loss. Heat loss via conduction, convection and radiation is aided or restricted by vasodilation or vasoconstriction, and so can be controlled to some extent by changes in the total insulation, and herice is thermoregulatory in nature.

(2) Eveporative hest loss.

The only other known method for losing heat is by the evaporation of water from moist body surfaces. Many homeotherms sweat, thus producing on their body surface wet area for evaporation. Some other homeotherms unable to sweat, create wet surface for evaportion by drooling copious quantities of salivg onto their body surface, and still others, incapable of sweating or drooling, evaporate water from their respiratory surfaces. Birds, because they lack sweat glands and do not drool, evaporate water for cooling from their respiratory surfaces by panting (Baldwin and Kendeigh, 1932; King ard Farner, 1961; Salt and Zeuthen, 1960). Pantinf, however, requires large expenditure of energy, which reduces its effi= ciency for cooling, as the metabolic rate and body temperature often became elevated as result of the animal's efforts. Species from several orders of birds, however, supplement panting with a resonant process known as gular fluttering. By gaplng their mouths and fluttering their highly vascularized, moist gular rea, these species can evaporate large quantities of water with little expenditure of energy, and so maintain their body temper tures for hours t ambient temperatures as high $47^{\circ} \mathrm{C}$ without incresing their metabolic rate. The mechanism of gular fluttering has been reported in pelicans and herons (Bartholomew and Dawson, 1954a), dopes (Fiartholomew nd Dawson, 1954b, boobles (Howell and Bartholomew, 1962), coprimulgids (Cowles and Dawson, 1951; Bartholomew et 21., 1962; 
Lasiewski and Dawson, 1964; Lasiewski and Bartholomew, 1966), and has been observed in cormorants, owls, and roadrunners. Evaporative cooling is physiologically active process, initiated the upper critical temperature (Figure 2 .

(3) The use of hyperthermis in eiding heat loss.

As the ambient temperature pproaches the body temperature heat loss vi condution, convection, and radiation becomes limited due to the decreased thermal gradient, but by storing het nd controlling its body temperature at new and higher level, the animal restores the critical thermal gradient to level which llows passive heat loss to be effective If the ambient temperature continues to rise, or the animal becomes active to the point of overheating, passive heat $108 s$ must be augumented with evaporative cooling. Becuse air can carry more water vapor as it warms, the hyper* thermic condition of the animal alds the process of evaporative cooling, making it quite effective at high temperatures. Once the body temperature hes reached the upper limit of safety, active cooling becomes more import ant, and finaliy if the ambient temperature exceeds the body temperature evaporative cooling is the only means by which body heat can be lost. Hyperthermis, therefore, is important in aiding both passive and active heat loss, though it is by its very nature self-limiting (King and Farner, 1964). Though body temperature in bixds is not adapted to climate (Ealdwin and Kendeigh, 1932; Irving and Krog, 1954; Wetmore, 1921), they have exw ploited their high body temper tures and their bility to tolerate periods of hyperthermi to ald physical and active cooling, as a preadation for inveding both hotodry and hot-humid climates. 
(4) The effectiveness of evaporative cooling in birds.

Several researchers, (Bartholomew and Dawson, 1953; Benedict nd Lee, 1937; Prush, 1965; Dawson and Schmidt-Nielsen, 1964; Hudson and Brush, 1964; Kayser, 1930, from Lasiewsk1, 1964; Wa11gren, 1954) using open flow metabolism apparatuses, tested the effectiveness of panting for evaporative cooling in small birds and concluded they were capable of losing only about $1 / 2$ of their metabolic heat production via this avenue. Several other species, however, when tested in this same type of apparatus were able to lose a11 of their metabolic heat (Bartholonew et el. 1962; Cade et $\mathbf{a}$. 1965; Calder, 1964; Ca1der and King, 1963; Calder and Schmidt-Nielsen, 1966; Lasiewski and Dawson, 1964; Lasiewski and Bartholomew, 1966; Lasiewski et a1. 1966). Laslewski et al. (1966) in series of experiments on evaporative water loss in birds, found that the effectiveness of evaporative cooling in open flow systems depends to a large extent upon the relative humidity in the animal chamber, and that the relative humidity in turn depends upon the rate of flow of initially dry air into the chamber.

The extent of evaporative cooling is directly related to the difference in water vapor pressure between the air and the evaporating surface (Burton and Edholm, 1955; King and Farner, 1964; Laslewsk1 et a1. 1966). In birds the water vapor pressure at the evaporative surfaces (mucosa of the bucal cavity, trachea, pulmonary system, and air sacs) approximates that of water the core temperature, and is therefore quite constant. The water yor pressure of the ir, which depends upon the relative humidity and air temperature, is variable (King and Farner, 1964). Therea fore, the higher the relitive humidity of the out ide ar, the smaller the difference in wer vapor pressure becomes, which restricts the loss 
of vapor from the evaporative surface. Hence, the efficiency of the evorative cooling becomes limited. In view of these facts, Laslewski et 1. (1966) felt the upper lethal amblent temperatures of birds obtained in open flow systems should be rechecked in light of the relative humidity in the chamber. These authors also believe all birds must be ble to dissipate all their met bolic het via evaporation at high ambient temperatures if the relative humidity is low.

C. The Standard ox Mlnimal Resting Metabolic Pate, and its Relation to the Environment.

1. The standard or minimal resting metabolism.

a The metabolic rate, weight relationship of mamma19.

Rubner, (1883, from Kleiber, 1961) deduced from his experiments with dogs and other homeotherms that fasting homeotherm would produce daily when at rest 1,000 Kcal of heat per square meter of body surface. This idea became accepted as Rubner's Surface Area Law of the met abolic rate. Benedict (1938) dowbted the validity of the Surface Area Law because of the large mount of contradictory data, and set out to find empirically more mecure method of expressing the standard metabolism. He standardiged conditions under which the metabolic rate could be considered minimal, a set of conditions closely followed even today; (1) the animal must be in ratural posture and complete rest, (2) he must be in post aborptive state, (3) the mbient temperature at the time of measurement must be witin the animiols pone of thermal meutrality, (4) the animal 5horfis not have been acclimated prior to the rests. (5) no emotional Btres ahorid be present, (6) the arimal should be in state of 
sexul repose, (7) the nitritive condition of the animal should be good, and (8) the animal should be ptime mature dult. Meeting these con= ditions in his own measurements of standard metabolism, and using data from other workers who had followed these conditions, he accumulated dat for animals varying in size from mouse to an elephant. He found, when the log of the total resting heat production of an nimal (Kcal/24 hrs,) is plotted geinst the log of the total weight $(\mathrm{Kg})$ and compared to similer plots of animels of different weights and species, Iinear increase in he production occurred with increasing weight. He further examed his collected dat for agreement with the Surface Area Law and concluded that metabolic heat production was not regulted by the gmount of surface area abalable for heat loss, but rather that heat loss must be regulated by the amount of heat produced. Scholander (1955) discussed climatic adaptations of homeotherms and expressed this same opinion and stated "the nondaptability of the resting rate shows that heat production is not. determined by het loss, es one might infer from the Surface Iaw of Bubner, but visa versa. Whatever the surface area happens to be, the heat 108 from it must be so regulated by various means that it blanaces heat production. In a homeotherm one might say the body temperature plays first violin, metabolic rate the second, and heat loss the third. The surface area is but one of the several factors which deternine heat los $\mathrm{s}^{\mathrm{*}}$. Klelber (196i) pointed out that the regression equation describing the $\log \circ \log$ plot of the metabolism to welght relationship of Benedict ${ }^{8}$ (1938) mouse to elephant curve, is wery similar to a curve produced by him 1 in 1932 for anim 18 varying in sige from dove to steer, and loter curwe in 1947 which included dota for animels ranging in size 
from a mouse to whale. In 11 instances the slope of the line demongtrated an expotential relationship between standard metabolism and body weight such that:

$$
\log M=\log +b \log W
$$

where MR is the metabolic rate in Kcal/24 hr, $W$ is the weight in $\mathrm{Kg}$, and a (the $y$ intercept) and $b$ (the slope) are empirically derived constants. Because of the direct relationship demonstrated on the log log plot, the equation can also be expressed as:

$$
M R=W^{b}
$$

with the symbols the sames bove. Kleiber (1961) concluded empiricalty, that the equation for mammals should read:

$$
\log M=\log 69+0.756 \log W
$$

that is "for all practical purposes one may assume that the mean standard metabolic rate of mamals is seventy times the $3 / 4$ power of their body weight (in $\mathrm{Kg}$ ) per day, or about $3 / 4$ power of their body weight (Kg) per hour"

b. The metabolic rate, weight relotionship of birds.

Though the lidity of Kleiber's (1961) equation is empiricily sound for mammals, some question as to whether it is vild to express the metabolic ratewelght relationship for birds a $3 / 4$ power of their weight has arisen.

(1) The Brody and Proctor equation:

Brody and Proctor (1932, from Lasiewski and Dawson, 1967) examined the dat for bixds and offered the following equation to describe their re 1.tionship:

$$
\log M=\log 89+0.64 \log w
$$


In their equation, the resting met bolism increases with an increase in weight at different rete than it does for mamals, and is expressed by an expont of 0.64 rather then 0.756.

(2) The Kirg and Farnes ejugtion.

King and Farner (1961) could not conceptualize on theoretical grounds why one homeothermic class should heve different metabolic rate weight reletiorship than nother. On this assumption they re-exemined the recint data, as well as that of Brody and Procter, and concluded the difference loy in the fact that the large birds used by Brody and Proctor had been measured at night, while the small ones had been measured during the day, Assuming a diunal varition in standard metabolic rate being the factor causing the difference in the Brody-Froctor eqution, they eliminated the dat for small birds, and arrived the following equation:

$$
\log \text { MR }=\log 74.3+0.744 \log W
$$

which is very clase to the equation given for mamals by Kleiber. They then combined the data for all birds, large and small alike, and produced this equation:

$$
\log M R=\log 80.1+0.659 \log w
$$

which is very similar to the Brody-Proctor equation. They concluded, however, that their first equation was a more valid theoretical expression of the met bolic rateongh relationship for birds becange it agred with the relstonsfip for manmals. They 130 asumed that the collection of more det on small birds would give the line curvilines quality at the lower weights.

(3) The Iasierski nd Dyrson equation.

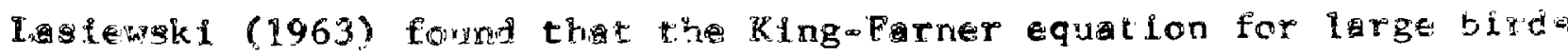
come clober to expressing the met bolism of his hummingbirds then the 
Brody-Proctor equation. In the same paper he agreed with a suggestion by Dawson that the King-Farner equation for large birds may represent the metabolism of non-passerines, while the Brody-Proctor equation, because it included koth passerines and nonpasserines, may come closer to representing the metabolism of passerines. Lasiewski and Dawson (1967) agreed with King and Farner's opinion that there should be no difference in the metabolic ret. weight relationship in the homeothermic classes, and re-examined all the data available for birds, on the basis that passerines as a group should show the same weight regression coefficlent as nonpasserines of comparable size. In their review of avian metabolism they concluded there was no diurnal variation in resting metabolic rate among birds and so clumped data collected t night with data collected during the day for each group. Their first eqia tion represents 11 the data avaliable for passerines:

$$
\log M R=\log 129+0.724 \log \mathrm{W}
$$

the second represents the data avallable for nonpasserines varying in size from hummingbirds to ostriches:

$$
\log M=\log 78.3+0.723 \log W
$$

and their third combines 11 the data for both passerines and nonpasserines:

$$
\log M=\log 86.4+0.668 \log W
$$

Their results demonstrate that the weight regression coefficient is essentially identical in both passerines and nonpasserines, but that passerines operate at a higher lepel of metabolism than nonpasserines of comparable $5 i \neq A$ Their equation representing 11 bixds is very similax in both slope (b) nd intercept (a) to the Brody-Proctor quation, but they consider this ar artifact of combining psserine and nonpaserine birds. They feal that the real signiticance of theis study lies in the agreement of the b-vitues fos 
the two groups of birds when considered separately, and that this provides support to the view that metabolism of both birds and mammals varies similaxly with body weight.

2. Resting metabolism and climate.

Scholander et al. (1950b) examined the standard metabolic rates of tropical and arctic animals in an attempt to find climatic differences between them. The resting metabolic rates of the species they studied fell very close to the regression line representing the mouse to elephant curve of Benedict (1938). These authors concluded that the standard metabolic rate is not adapted to climate, a view subsequently supported by other studies on arctic and subarctic species (Irving et $\underline{\text { 1. }}$ 1955; Krog et al. 1955). In 1955, Scholander wrote ". . basal heat production has been found to be essentially the same in all climates, inasmuch as most arctic, temperate, and tropical mamnals fit the mouse to elephant curve of Benedict (1938). Birds show this regularity too. This leaves heat dissipation as the only major avenue for phylogenetic adaptation to climate".

a. Adaption of the metabolic rate by hibernators.

Because the poor-will hibernates, and the pauraque (Nyctidromus albicollis) another caprimulgid, has a standard metabolic rate below the predicted value for comparably sized passerines, Scholander et al. (1950b) attributed the pauraque's low metabolic rate as an adaptation possessed by 11 hibernators. This concept though interesting is yet to be proven. In a later study Lawiewski and Dawson (1964) demonstrated with their data for the common nighthawk, and Scholander et $.1^{\circ} \mathrm{s}$. (1950b) data for the pauraque, that even though the standard metabolic rates of these two caprimulgids are below the predicted value for passerines, they fit the King-Farner (1961) 
equation for nonpesserines fairly well, with the pauraque being somewhat higher then predicted. Since these authors further found that only starva tion induced torpor in the common nighthawk it would appear that neither the pauraque nor the common nighthawk possess any special metabolic adaptations which may be common to hibernators.

Benedict (1938) found that the marmot, hibernator, had atandard metabolic rate far below those of other comparably sized homeotherms, and that unlike a goose of comparable size, a rapid gain in weight from fat deposition in the marmot did not increase its standard metabolic rate is did in the goose. He concluded that the marmot's fat, unlike goose fat, must be metabolically inactive. Hudson (1962) in presenting his and Bartholomew"s unpublished observations on the round-tailed ground. squirrel (Citelius tereticaudus) and the pigmy opossum (Cercaertus nana), found that the fat deposits in these hibernators exerted little effect on their standard metabolism. They cautioned, therefore, that before low standard metabolism can be used as a phenomenon characteristic of hibernators, rates for comparison with those of nonhibernators should be calculated on a fat free basis. Hudson (1962), therefore, states that hibernation may either allow or follow low basal metabolism.

b. Adaptation of the metabolic rate for life in hot arid climates.

Hudson (1962) reported that desert animals are often faced with ambient temperatures that demand maximal effort toward heat dissipation, and therefore, proposed that if diurnal forms in this environment had lower standard metabolic rate, it would reduce the problem of heat dis sipation. Bartholomew et al. (1962) offered as an example of this type of climatic adaptation, the poorwill (Phalaenoptilus nuttallii), coptimulgid 
that nests in the open, exposing itself throughout the day even in the desert, to severe insolation. This bird possess a standard metabolic $r y^{4} \mathrm{e}$ of $1 / 3$ the predicted value, which undoubtedly contributes to the birds efficiency in cooling itself at the extremely high ambient temperatures i* encounters.

Another possible adaptation of the standard metebolic rate ta the environment is described in review by Hudson and Bartholomew (1964) whts they mentioned that an animal's entry into torpor at high ambient terferts would be facilitated by its having a lower critical temperature above the ambient temperatures to which it is normally exposed. Morrison (1960) 50.27 this adaptation would be useful to diurnal homeotherms living in hot eritronnts. Interestingly enough this aptation has recently been found not 10 irnd animals, but rather in the small nocturnal rodents living in the hot rid rei ns of the southwestern United States. Many of these opecies which estivt op show signs of dally torpor, do not possess conspicuous fat deposits, but th have unusually low metabolic rates within their zone of thermal neytrily. As a result of their lowered metabolic rate, their lower critical tewperat is high, being above the ambient temperatures to which they normally exposed. This allows these animals to enter the torpid st te and lower their body temperatures at relatively high ambient temperatures (Hudson ac:! Bartholomew, 1964). The phenomenon of torpor at high ambient temper tures and lowered metabolic rate have been found in the kengaroo mouse, Mics lit podops pallidus, (Bartholomew and MacMillen, 1961); the pigmy mouse, givy,

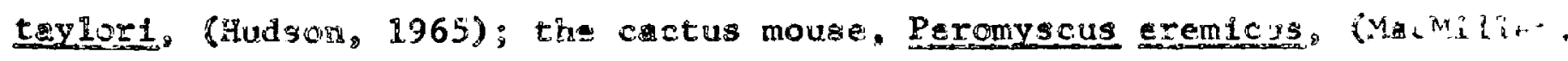
1965); the brush mouse, geromyseus boylei, and the pinon mouse, Paromys.truei, (MacMilen, 1965; from persongl communication with Hudson, 965): an: 
the California pocket mouse, Perognathus californicus, (Tucker, 1962); 11 of which re nocturnal. Two other southwestern rodents capable of torpor at high ambient temperatures, but which are diurnal in habit are the mohave ground squirre1, Citellus mohavensis, (Bartholomew and Hudson, 1960), and the roundtailed ground squirrel (Hudson, 1964). Significantly the diurnal antelope ground squirrel, Ammospermophilus leucurus, neither hibernates nor estivates, and does not show a reduced resting metabolism (Hudson, 1962 , from Hudson and Bartholomew, 1964). MacMilien (1965) in analyzing the advantages of a low standard metabolism, and its application to aestivation in the cactus mouse, pointed out that torpor at the relatively high ambient termperatures at which it must occur in the burrow during the summer, may operate not only s water conserving mechanism, but lso as mens of prolonging food stores.

We see, therefore, that the standard metabolism has been adapted in some cases to allow survival, especially in hot arid regions (Eartholomew et al. 1962; Hudson, 1962; Hudson and Bartholomew, 1964; MacMi1lan, 1965) where heat $10 s$ and water conservation are factors directly concerned with and benefited by a below normal standard metabolic rate.

II. The Present Study

The red-breasted nuthatch (Sitta canadensig) is a small bird resident in the coniferous forests of the north temperate region of North America ranging as far north as Anchorage, Alaska, in the west, and James Bay, and Fewfoundland, in the est. They are found as far south as southern Califix ornia, southesstern Arlzone, nd southcentral Colorado in the west, nd estern Teanesses, and western North Carolina in the east. Populations it high latitudes and ltitudes my migrate erratically and records indicate 
these nuthatches are found occesionally during the winter as far south as southern Arizona, southern New Mexico, Texas, southern Louisiana, southern Mississippi, and northern Florida (AOU Checklist, 1957).

Their widespread distribution presents them with an extremely wide range of yearly temperatures. In the Rattlesnake area near Missoula, Montana, where I trapped several of these birds, they may encounter ir temperatures in the winter low $-36^{\circ} \mathrm{C}$ to $-40^{\circ} \mathrm{C}$ (Bakus, 1959). Summer temperatures have been reported in excess of $38^{\circ} \mathrm{C}$ at the Missoula County Airport (Fersonal communication), though in the shaded forests where these birds are found, the high summer temperatures are probably much lower. Even so these birds may encounter $70^{\circ} \mathrm{C}$ or more yearly change in temperature in the Missoula area.

Because of their small gize (weight range from 9.8 to $14.5 \mathrm{~g}$ ), the effectiveness of their feathers as insulation may be reduced, and the rete of heat loss from their bodies at low ambient temperatures may be relatively high. To equate heat loss with heat gain, therefore, heat production may be elevated during the colder parts of the year. In the winter months as the number of daylight hours for foraging diminish, and heat production is elevated, maintainance of the energy balance may become a problem. During the summer the problem is reversed, becoming one of dissipating enough heat to balance heat gain with heat loss. The thermoregulatory problems that this sma 11 bird foees in its environment make it a subject of interest to the physiologist.

It has been the purpose of this study, therefore, to examine the metabolic, ewgorative, nd insulative capabilities of the red-breasted 
nuthatch when taken from the field at different seasons and presented with - wide range of ambient temper tures under controlled laboratory conditions. Metabolic rate was measured and recorded in terms of oxygen consumption over $73^{\circ} \mathrm{C}$ temperature range. The production of $\mathrm{CO}_{2}$ was measured over this entire range of ambient temperatures during certain intervals of $\mathrm{O}_{2}$ consumption, to determine via the resultant respiratory quotient, the nature of the food products being catabolised. To evaluate the relative effectiveness of the bird's mechanism for evaporative cooling, water loss was sometimes measured along with oxygen consumption at ambient tempertures above $0^{\circ} \mathrm{C}$. The effectiveness of the insulation was determined indrectly from the record of oxygen consumption by the presence and extent of the zone of thermal neutrality. 


\section{MATERIALS AND METHODS}

\section{Trapping and Maintainance.}

For the experiments conducted from May, 1966, to September, 1966 , and from January, 1967, through February, 1967, I captured 20 red-breasted nuthatches near Missoula, Montana. Ten were taken from January through March, 1966, six from June through August, 1966, and four from December, 1966, through February, 1967. All the winter-caught birds came either from fattiesnake Creek, 5 miles north of Missoula, or from lower Pattie Canyon, 4 miles east of Missoula. Early in the summer, from June to the middle of Iuly, I trapped on Rattlesnake Creek. All of these sites were at elevations between 3400 and 3500 feet (United States Department of Interior Geological Survey, 1903). Late in the summer, from the end of July to the end of August, the birds apparently moved to higher elevations and were trapped in upper Puttie Canyon, 6 miles east of Missoula, televations of about 5000 feet (Urited States Department of Interior Geological Survey, 1903).

In 11 cases the birds were collected in a ponderose pine (Einus ponderosa) forest. Along the stream bottom on Rattlesnake Creek, this pine was in association with northern black cottonwood (Populus trichocerpa), whereas in Pattie Canyon ponderosa pine forests dominated south-facing slopes, but were in association with Douglas-fir (Pseudotsuga taxifolia) and western larch (Lerch oxidentalis) on north-facing slopes.

During the winters, three to four chicken-wire baskets filled with suet, each tied to the trunk of tree at about chest height were used to attract the nuthatches and to accustom them to feeding in one particuiar area during parts of their daly foraging cycles. Though successul in the winter, these feeders did not attract the birds during the summer. 
Other wintering birds also seem feeding at the suet baskets were the blackbilled magpie (Pica pica), black-capped chickadee (Parus antricapillus), mountain chickadee (Parus gambeli), hairy woodpecker (Dendrocopos yiliasis;, brown creeper (Certhie familiaris), downy woodpecker (Dendrocopos pubescers), Clark's nutcracker (Nucifraga columbiana), golden-crowned kinglet (Zegulue strapa, and white-breasted nuthatch (Sitta carolinensis).

The red-breasted nuthatches proved difficult to capture in mist nets, but could easily be live-trapped in small $(40 \times 20 \times 20 \mathrm{~cm})$ bor traps, constructed of $1 / 2$ inch mesh hardware cloth, of the type uged by McCowery (1961) to trap chickadees. These were baited with suet and/or mealworms (Tenebrio molitor) and placed on a horizontal branch within 50 feet of the feeders. Each trap was equipped with perch which functioned as trigger, but which proved unreliable. Consequently $\bar{I}$ released the trigger manually via string. During those days or hours of the day when the traps were left unattended, their doors were locked open to encourage their use as regular feeding spots.

In the summer, a meal-worm balted trap, attached to small portable decoy cage containing a captive nuthatch, was positioned either in a tree or on stump near tree. The decoy by his calling atracted another nuthatch, and fter period of mutuel displaying, the attracted bird would be lured by the neal-worms into the trap.

After capture, the birds were banded, placed in small indoor cages and llowed to adjust to ceptivity. An ed libitum diet of mel-worms, wh spanish pegnuts, peanut butter, and water was provided. The birds adaptad repidiy, eating and drinking freely soon after capture and aome individutis accepted meal-worms from the hand the sane day they were captured. 
After the initial adjustment period the birds were turned into a large $6 \times 6 \times 9 \mathrm{ft}$ outdoor flight cage, containing a wooden floor, a sloped asphalt papered roof, and sides and doors of galvanized window screen. Maintained in this manner, they were constantly exposed to the natural photoperiods and temperatures of the Missoula area. Nest boxes, logs, stumps, branches, and small conffers placed within the cage allowed the birds to perch, climb, and hide. Suet, raw spanish peanuts, a peanut butter-bacon fat mixture, water in the form of free water or snow, and 20 to 30 meal-worms per bird, per day, kept the birds vigorous and healthy, and maintained their weight between 11 and $14.5 \mathrm{~g}$. Immediately fter capture, summer birds and those caught in the second winter, weighed from 9.8 to $11 \mathrm{~g}$, but gained 1 to $2 \mathrm{~g}$ in captivity.

II. Experimental Procedures:

All birds used in the experiments were kept in small cages in the laboratory with food and water provided ad libitum, for at least 12 hours before testing. They were weighed on a Mettler balance to the nearest $0.01 \mathrm{~g}$, before and fter each test period. At temperatures from $-16^{\circ} \mathrm{C}$ to $39^{\circ} \mathrm{C}$, test periods were 6 to 9 hours in length, and two determinations, each at particular temperature separated by not less than $10^{\circ} \mathrm{C}$ or more than $20^{\circ} \mathrm{C}$, were conducted for each period. At temperatures from $-30^{\circ} \mathrm{C}$ to $-17^{\circ} \mathrm{C}$ and from $40^{\circ} \mathrm{C}$ to $43^{\circ} \mathrm{C}$, test periods did not exceed $21 / 2$ hours in length, and ylelded one determination at one particular temperature per test period. Only those low values constant over at least 2 min period (King, 1964) were selected for calculating $\mathrm{O}_{2}$ consumption. In many cases constant values were obtained for periods exceeding 20 min. 
Those records not meeting these minimum requirements were not used. $\mathrm{CO}_{2}$ production was determined over the entire $73^{\circ} \mathrm{C}$ temperature range, but evaporative water loss was measured only at temperatures above $0^{\circ} \mathrm{C}$.

Any birds showing signs of molting or unusual weight loss were not used in the experiments. In those experiments conducted from May, 1966, to September, 1966, $0_{2}$ consumption was measured in six of the 10 birds caught during the first winter, and all six of the summer caught birds. The summer caught birda also provided data of $\mathrm{CO}_{2}$ production and evaporative water loss. Those four birds caught during the second winter, provided dat of $\mathrm{O}_{2}$ consumption, $\mathrm{CO}_{2}$ production, and evaporative $\mathrm{H}_{2} \mathrm{O}$ loss during measurements carried out from January, 1967, through Februery, 1967. A Beckman paramagnetic oxygen anglyzer monitered $\mathrm{O}_{2}$ consumption which was recorded by a Brown single strip recorder. Silica gel and acarite were used to gravimetrically determine evaporative $\mathrm{H}_{2} \mathrm{O}$ loss and $\mathrm{CO}_{2}$ production, respectively. The apparatus used for the experiments (Figure 3) allowed either single or simultaneous measurement of any one of the above parameters. A small aquarium pump provided the air flow which passed successively via rubber, copper, and glass tubing connections to, (1) a surge tank, (2) cylinders of silica gel and ascarite for removal of water vapor and $\mathrm{CO}_{2}$ from the ir, (3) valve controlling the air flow through the metabolism chamber, (4) metabolism chamber contained in a constant temperacure cobinet, (5) a pressure gauge, (6) a second, "double", system of chemical absorbants for removal and testing of the respiratory products from the poot chamber ir flow, (7) a flow meter, (8) a bleeder valve for pressure regulation, (9) ga selector pane1, (10) a final dehydration cylinder, (11) a cotton filter, nd (12) the Eeckman oxygen analyzer. 
Flow retes in this open system were regulated from $320 \mathrm{cc}$ to $628 \mathrm{cc}$ of air per min (uncorrected to STP), and pressures in the metabolism chamber were maintained between 6 to $12 \mathrm{~mm} \mathrm{Hg}$, which gave an absolute pressure to the system between 670 and $690 \mathrm{~mm} \mathrm{Hg}$.

Coiling of the tubing in the constant temperature cabinet allowed the air to be cooled or warmed to the test temperature before it entered the metabolism chamber. The metabolism chamber consisted of a new one gallon pint can, the lid of which was fitted with (1) an inlet port which extended $3 / 4$ of the way into the can to allow complete circulation of air within the chamber, (2) an out let port, and (3) an arrangement for a thermistor probe with which to monitor the temperature within the chamber. A $1 / 2$ in mesh hardware cloth floor, set about $7 \mathrm{~cm}$ from the bottom of the can on legs constructed from copper tubing, held the bird away from the bot. tom which was covered to depth of about $2 \mathrm{~cm}$ with mineral oil. The mineral oil served to trap feces rolded by the bird, thereby eliminating the possible addition of fecal and urinary water to the system. The chamber lso contained perch on which the bird could sit in a normal posture.

The freezer chest of a refregerator was converted into a controlled temperature cabinet by placing in it, a hair dryer wired to a manualiy controlled thermost and variable transformer. The heating element of the hair dryer thus opposed the refrigerating unit to keep any temperature within the range from $16^{\circ} \mathrm{C}$ to $43^{\circ} \mathrm{C}$, constant within plus or minus $0.5^{\circ} \mathrm{C}$. Dry ice placed in the temperature cabinet, kept temperatures constant to plus or minus $1^{\circ} \mathrm{C}$, below $-16^{\circ} \mathrm{C}$. 
Figure 3-Schematic diagram of the apparatus.

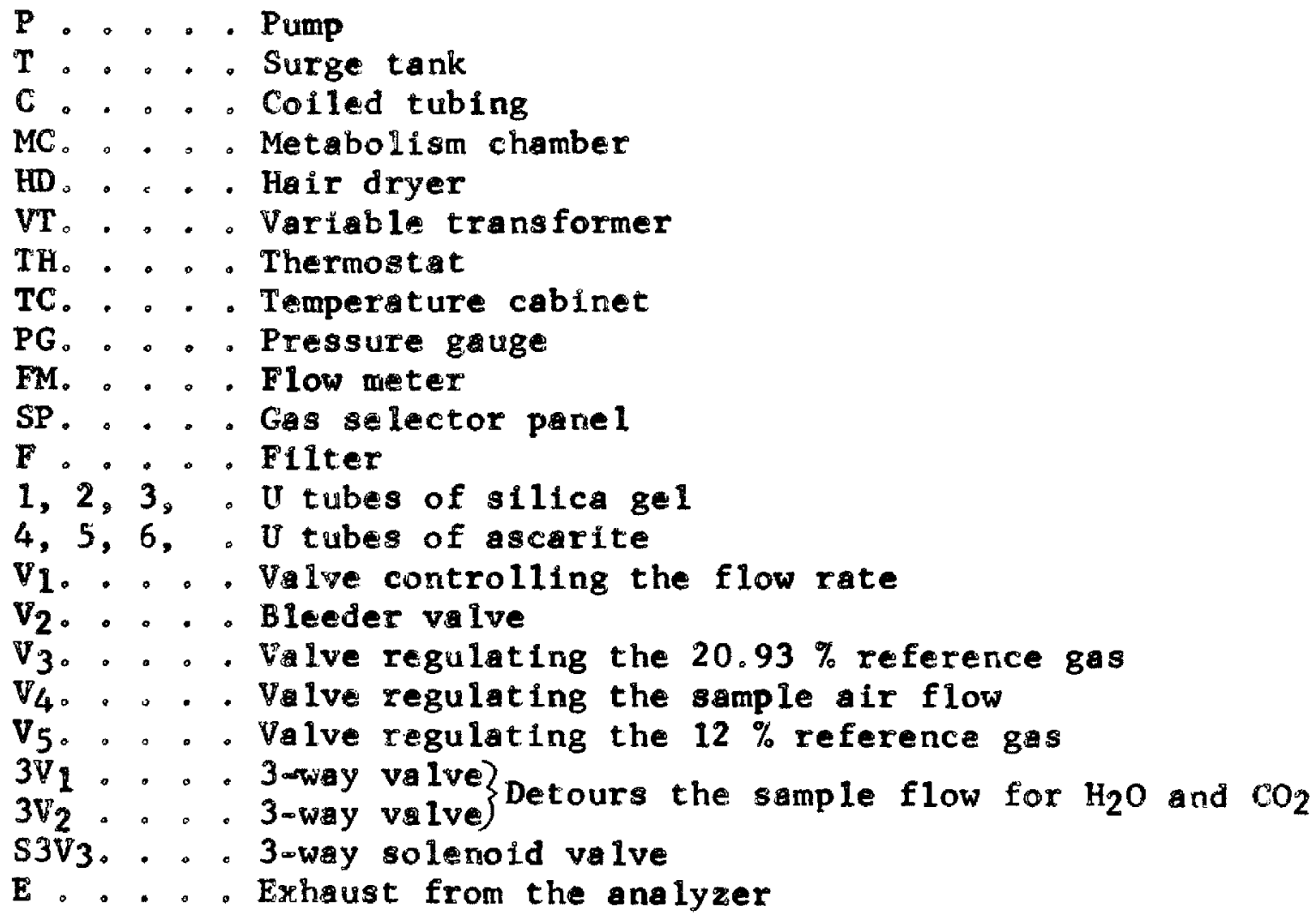




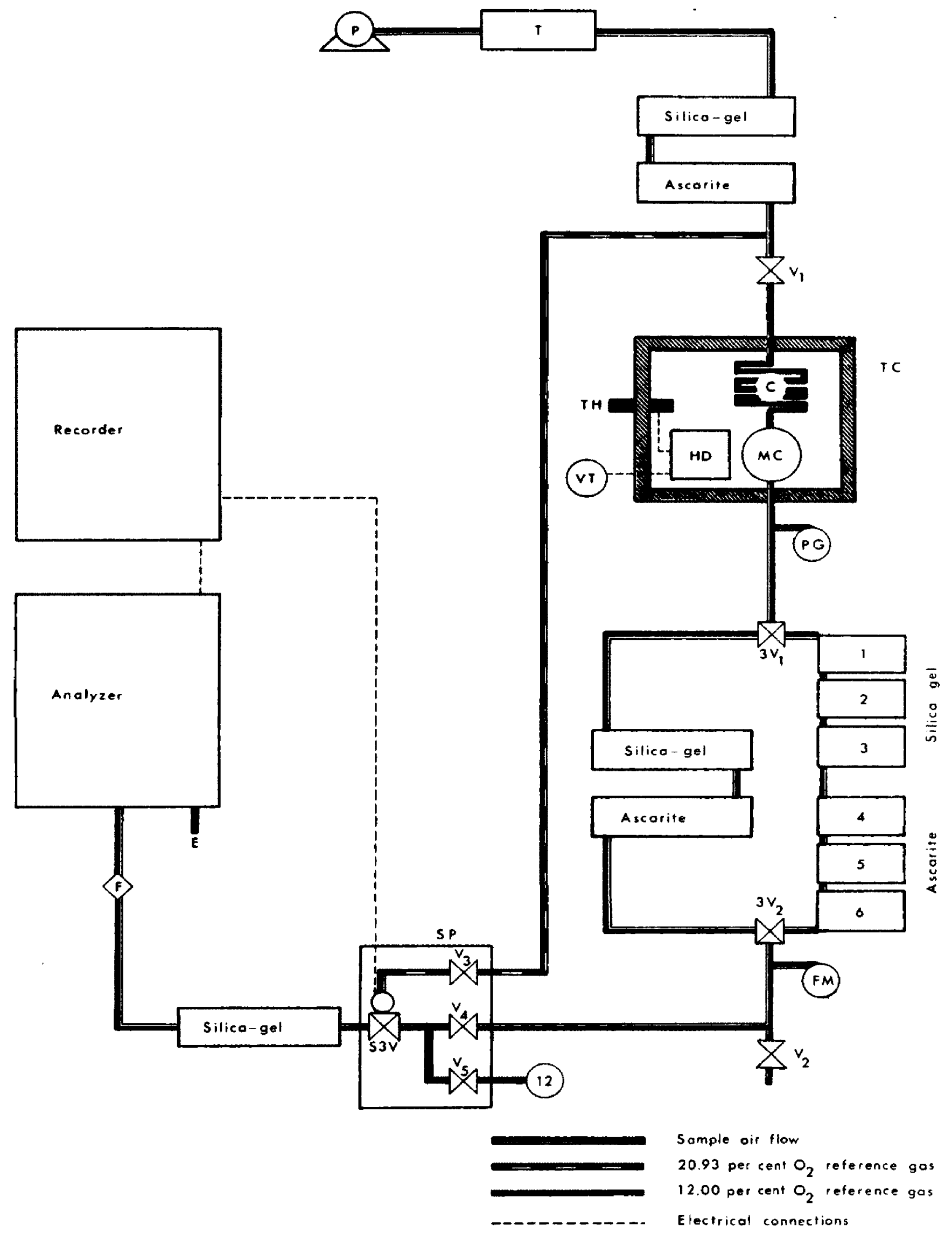

Reproduced with permission of the copyright owner. Further reproduction prohibited without permission. 
The pressure gauge, calibrated to be read in $\mathrm{mm}$ of $\mathrm{Hg}$, installed in the flow line near the out let port of the animal chamber, consisted of a mannometer tube containing Brody's mannometer fluid. The flow meter, calibrated to be read in cc of air/min, installed in the flow line just downstream from the $\mathrm{CO}_{2}$ and $\mathrm{H}_{2} \mathrm{O}$ vapor sampling system, consisted of a glass $U$ tube containing Bordy ${ }^{\circ} s$ mannometer fluid, which utilized the Venturi effect to indicate the volume of air (uncorrected to STP) flowing through the animal chamber.

During 20 minute intervals of some experiments, ir from the out let port was diverted to a detour line, and passed through three $U$ tubes each, of silica gel and ascarite. These chemical aborbants were used to gravimetrically determine to the nearest miligram the evaporative $\mathrm{H}_{2} \mathrm{O}$ loss and $\mathrm{CO}_{2}$ production, respectively, of the bird being tested. Cylinders of like, chemical absorbants in the main flow line, dryed and removed the $\mathrm{CO}_{2}$ from the post chamber air when $\mathrm{O}_{2}$ consumption lone was being tested. Periodic tests using an empty metabolism chamber, indicated there were no leaks or water vapor in the apparatus.

A needle valve in the gas selector panel allowed aliquots of sample air, at $150 \mathrm{cc} / \mathrm{min}$, to enter the analyzer. Two other needle v\&lves in the gas selector panel regulated the flow into the analyzer of either, dry room air containing $20.93 \% \mathrm{O}_{2}$, or commercially mixed gas containing $12 \% \mathrm{O}_{2}$. These were used as reference gases to set the zero point arid span, respectively, of the analyzer. The andyzer could then detect the $\mathrm{O}_{2}$ concentration of gas mixture containing from $12 \%$ to $20.93 \% \mathrm{O}_{2}$. For more complete description see the Beckman Instruction Manual No. 81043--B, 1962). From the gas selector panel, the ir from either of 
the three valves passed through final cylinder of silica gel, and a cotton filter before entering the analyzer.

The analyzer determined the partial pressure of the $\mathrm{O}_{2}$ in an liqout of air flowing into it by measuring its magnetic susceptibility, Because $\mathrm{O}_{2}$ if highly paramagnetic and the other atmospharic gases are weakly dig= magnetic, the $\mathrm{O}_{2}$ molecules placed in a magnetic field act s temporary magnet, analogous to a piece of soft iron in magnetic field. The other gases in the sample being diamagnetic, act as non-magnetic particle in a magnetic field (Beckman Instruction Manual, 81043--B, 1962). The analysid cell of the analyzer constantly detects any change in the partial pressure of the $\mathrm{O}_{2}$ in the sample. This information is transmitted electrically to the Brown single strip recorder, where it is continuously transcribed in a moving chart, not as partial pressure but as percent of $\mathrm{O}_{2}$ present in the sample. From this recorded reduction in concentration, and the rate of flow, the rate of $\mathrm{O}_{2}$ consumption per $g$ body weight per hour, can be calculated using conversion factors and equation (10) of Dapocas nd Hart (1957).

The corrected volume of air flowing through the animal chamber was calculated using the following conversion factor:

$$
v_{e}=\left(V_{1}\right)\left(\frac{263}{(273+T)}\left(\frac{T P}{T}\right)\right.
$$

where $V_{e}$ is the volume of dry gas at $0^{\circ} \mathrm{C}$ and $760 \mathrm{~mm} \mathrm{Hg}$; $\mathrm{V}_{1}$ is the original volume; is is the temperature in degrees centigrade; and IP is the barometrie presure plus the pressure in the system. 
The partal pressure of $\mathrm{O}_{2}$ in both the inlet and outlet ports was determined according to the following equations:

$$
\begin{aligned}
& { }^{{ }^{P}} \mathrm{IO}_{2}=\left(\% \mathrm{IO}_{2}\right)(\mathrm{BP}) \\
& \mathrm{P}_{\mathrm{IO}_{2}}=\left(\% \mathrm{EO}_{2}\right)(\mathrm{BP})
\end{aligned}
$$

where $\mathrm{P}_{2}$ is the partial pressure of $\mathrm{O}_{2}$ in the inlet ir; $\mathrm{PEO}_{2}$ is the partial pressure of $\mathrm{C}_{2}$ in the outlet ir; $\% \mathrm{IO}_{2}$ is the percent of $\mathrm{O}_{2}$ in the inlet air $\left(20.93 \%\right.$ constant); $\% \mathrm{EO}_{2}$ is the percent of $\mathrm{O}_{2}$ in the outlet air (from the nalyzer record); and EP is the barometric pressure.

Oxygen consumption was then calculated from the Depocas and Hart (1957) equation:

$$
v_{0}=v_{e} \frac{P_{\mathrm{IO}_{2}}-{ }^{P_{\mathrm{EO}_{2}}}}{\mathrm{EP}-{ }^{P_{\mathrm{IO}_{2}}}}
$$

where $v_{0}$ is the $o_{2}$ consumption per minute: $v_{e}$ is the volume of dry air $0 \circ \mathrm{C}$ and $760 \mathrm{~mm} \mathrm{Hg} ; \mathrm{P}_{\mathrm{IO}}$ is the partial pressure of $\mathrm{O}_{2}$ in the inlet port: $\mathrm{P}_{\mathrm{EO}_{2}}$ is the partial pressure of $\mathrm{O}_{2}$ in the outlet air; and $\mathrm{BP}$ if the baro. metric pressure.

The $\mathrm{O}_{2}$ consumption per minute was then converted to the $\mathrm{O}_{2}$ consumed per gram body weight per hour.

A11 20 minute $\mathrm{CO}_{2}$ and $\mathrm{H}_{2} \mathrm{O}$ vapor collections were taken only when the rate of $\mathrm{O}_{2}$ consumption was constant and indicated the bird was at rest. Water loss measurements were extrapolated to represent an hour and plotted as milligrams of $\mathrm{H}_{2}$ O lost per gram body weight per hour. The weight of the $\mathrm{CO}_{2}$ measured was extrapolated to represent an hour. It was then converted to qulum $\left(\mathrm{Lg} \mathrm{CO} 2=1.977 \mathrm{LCO}_{2}\right)$ and divided by the $\mathrm{O}_{2}$ consumed during that same perios to give the respiratory quotient. The ratio of heat lost to heat Froduced (the /p retio) wa calculated using $4.8 \mathrm{Kc} 1 / \mathrm{I}$ as the caloric equio galant of the $\mathrm{O}_{2}$ consumed, and $.58 \mathrm{Kcal} / \mathrm{g}$ as the heat of vaporization of the 


\section{RESULTS}

I. Oxygen Consumption.

Oxygen consumption increases linearly when plotted with decreasing temperature from $30^{\circ} \mathrm{C}$ to $-15^{\circ} \mathrm{C}$ (Figure 4). The regression line representing this increase is expressed by the equation:

$$
\mathrm{cc}_{2} / \mathrm{g} \times \mathrm{hr}^{-1}=10.20-.20 \mathrm{t}
$$

where $t$ is the ambient temperature. At temperatures below $-15^{\circ} \mathrm{C}$, values for oxygen consumption become more scattered and several points rise mark. edly above the linear relationship. The regression Iine of increasing oxygen consumption extrapolates to zero metabolism at about $51^{\circ} \mathrm{C}$ which is far above the range of normal body temperatures $\left(42^{\circ} \mathrm{C}\right.$ to $43^{\circ} \mathrm{C}$ from Wetmore, 1921).

These birds consumed the least amount of oxygen between ambient temperatures of $30^{\circ} \mathrm{C}$ to $39^{\circ} \mathrm{C}$. The basal or resting rate of oxygen consumption calculated from data within this temperature range is $3.71 \mathrm{cc}$ $\mathrm{O}_{2} / \mathrm{g} \times \mathrm{hr}^{-\mathrm{I}}$. At $40^{\circ} \mathrm{C}$ and above oxygen consumption increases with increasing temperature to values between 4.2 and $7.0 \mathrm{cc} \mathrm{O}_{2} / \mathrm{g} \times \mathrm{hr}-1$.

The metabolism of summer birds in response to changing temperatures does not differ from that of winter birds.

\section{Evaporative Water Loss.}

Evaporative water loss increases directly with increasing temperature, though not at constant rate (Figure 5). From $0^{\circ} \mathrm{C}$ to $21^{\circ} \mathrm{C}$ water $10 \mathrm{~s}$ is relatively constant and remains below $5 \mathrm{mg} / \mathrm{g} \times \mathrm{hr}-1$. From $22^{\circ} \mathrm{C}$ to $39^{\circ} \mathrm{C}$ water loss increases gradual1y. Over this $17^{\circ} \mathrm{C}$ interval the $\mathrm{Q}_{10}$ is about 2.2. At $40^{\circ} \mathrm{C}$ and above, water loss values increase tremendously. 
Figure 4-oxygen consumption of the red-breasted nuthatch in cc $\mathrm{O}_{2} / \mathrm{g} \times \mathrm{hr}-\mathrm{i}$, plotted in respect to ambient temperature $\left(\mathrm{T}_{\mathrm{a}}{ }^{\circ} \mathrm{C}\right)$. Closed circles represent sumer birds and open circles winter birds. 


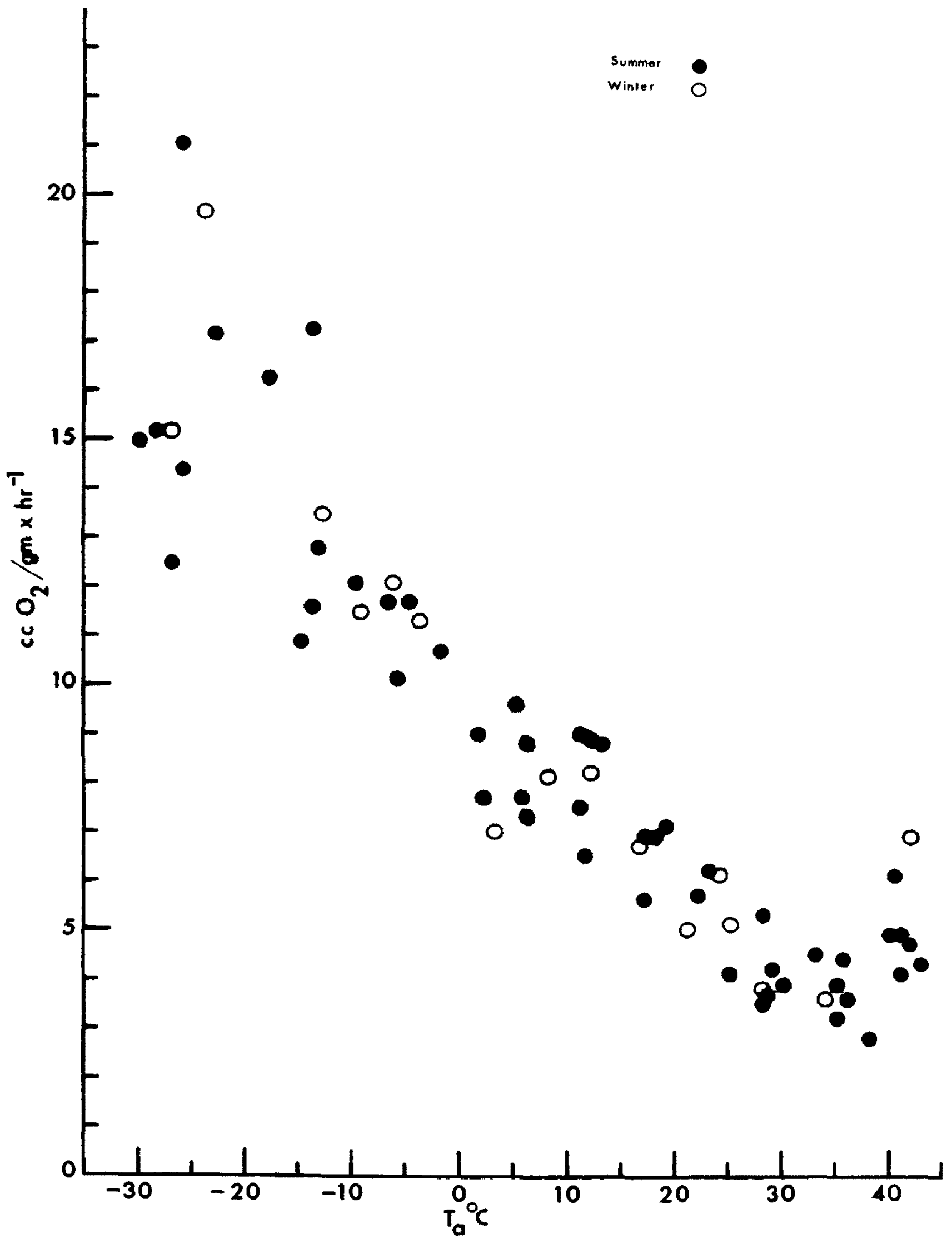


Figure 5-aEvaporative water loss of the red-breasted nuthatch in $\mathrm{mg} / \mathrm{g} x$ $h_{r}-1$, plotted in respect to ambient temperature ( $\left.T_{a}{ }^{\circ}\right)$. See legend for figure 4 . 


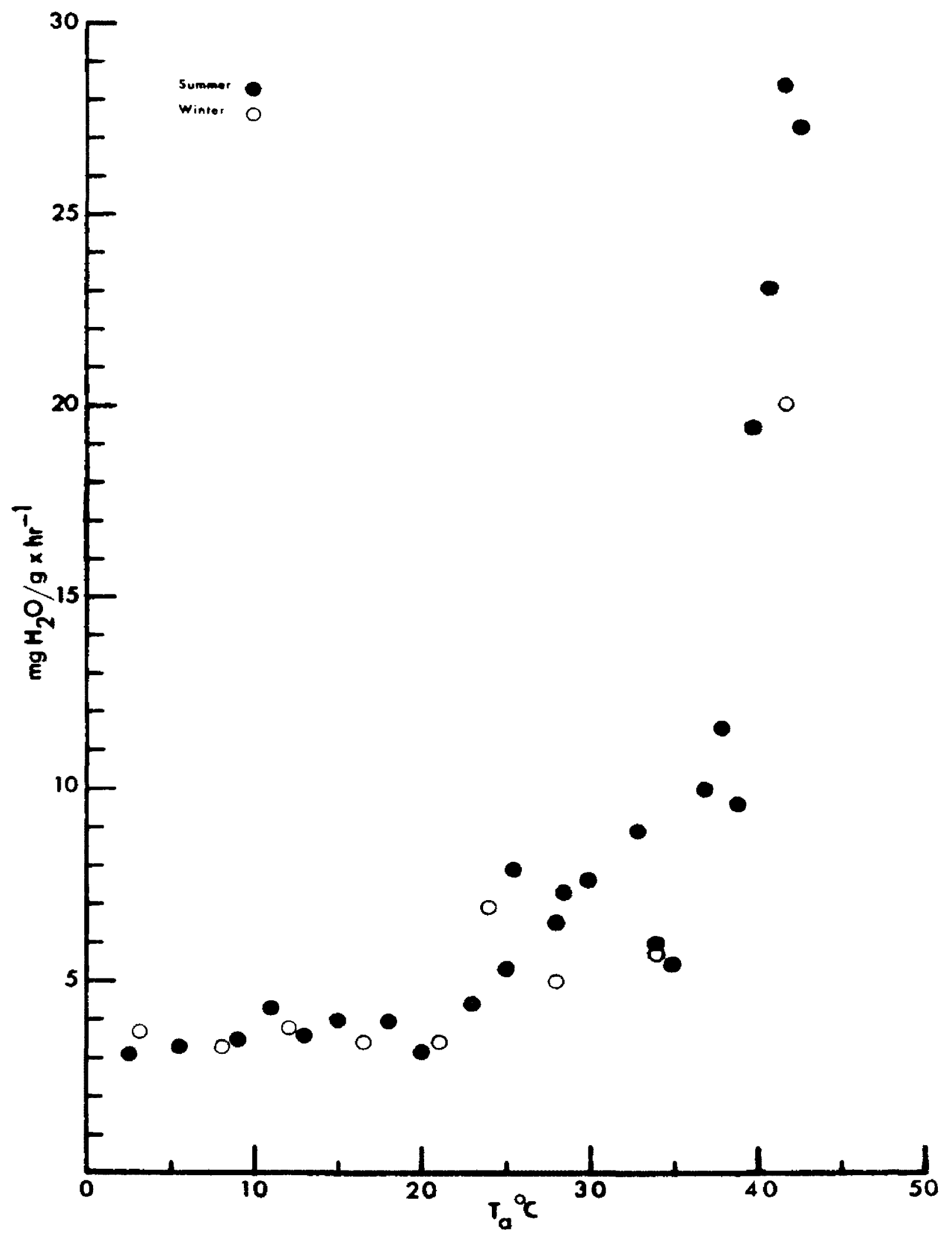


III. The Raspiratory Quotient.

Experimental respiratory quotients for the red-breasted nuthatch ranged from 0.43 to 1.3 . These were plotted in relation to temperature in Figure 6. The graph shows correlation of low respiratory quotients at low ambient temperatures and high respiratory quotients at high ambient temperatures. The sumer birds (closed circles) show the greatest variation giving both the highest and lowest values at both the upper and lower ends of the temperature scale. The values for the winter birds (open circles) fit the scatter of summer values except at temperatures above $25^{\circ}$ where they are below the scatter of summer values. 
Figure 6--Respiratory quotient (R. $Q_{0}$ ) of the red-breasted nuthatch as plotted against temperature $\left(\mathrm{T}_{a}{ }^{\circ} \mathrm{C}\right)$. See legend for Figure 4. 


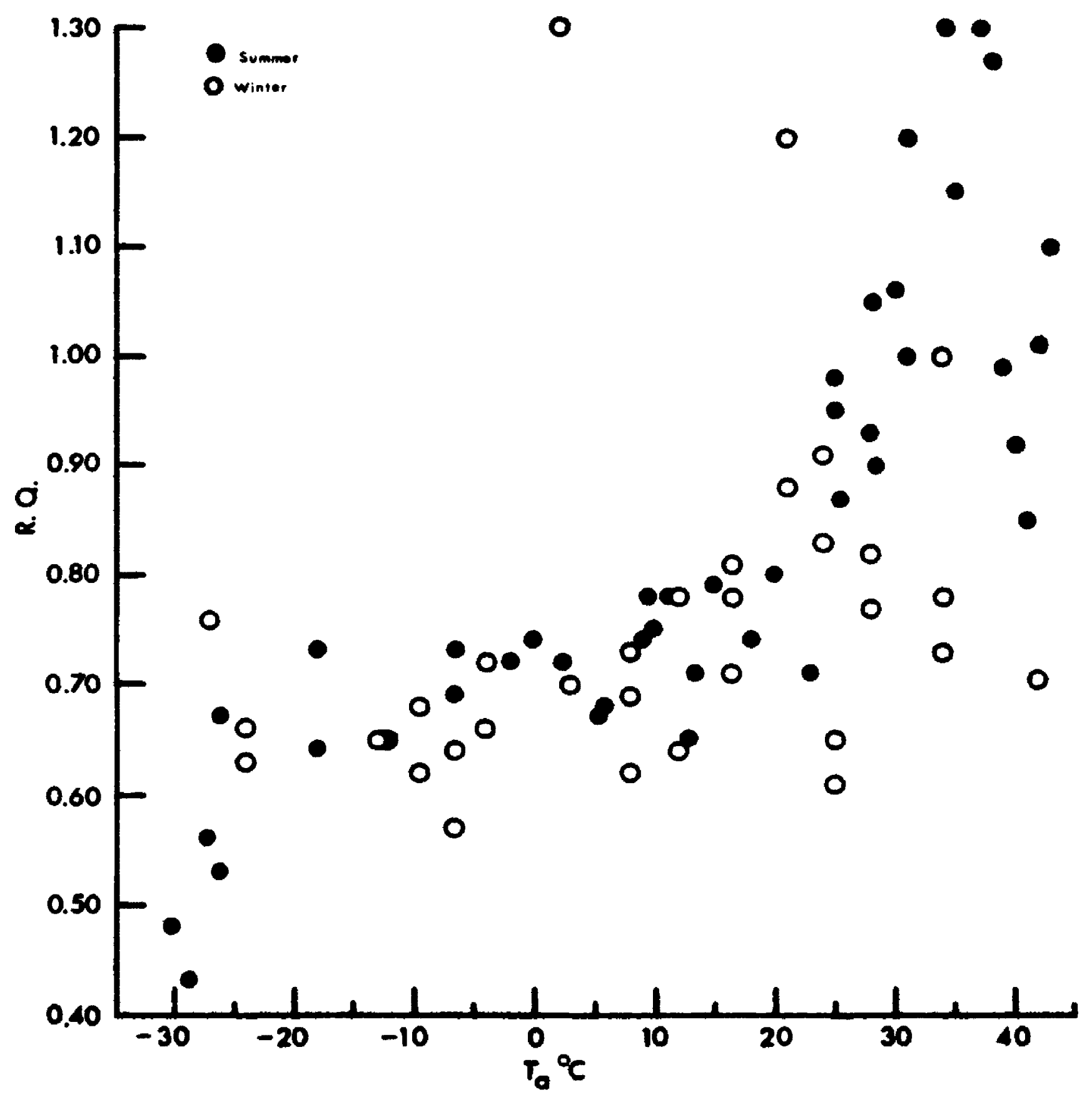




\section{DISCUSSION}

\section{The Resting (basal) Matabolic Rate.}

The resting metabolic rate of the red-breasted nuthatch is compared in Table 1 with those values predicted for a bird of comparable size by the various equations available. The resting rate of the nuthatch is very similar to the value predicted by Lasiewsici and Dawson (1967) for pesseriris, but is more than $40 \%$ higher than those values predicted for comparably sized bird by the Lasiewski and Dawson (1967) equation for nonpasserines, or the King and Farner (1961) equation for large birds. These comparisons agree with Lasiewski and Dewson's hypothesis that passerines have a greater metabolic rate than nonpasserines of comparable size, and that the metabolic rate-body weight curve for passerines has the same slope as that for non. passerines, but its $y$ intercept is higher. The metabolic rate of the red. breasted nuthatch is twice that of a comparably sized mammal.

II. Energy Requirements in the cold.

The increase in oxygen consumption below $30^{\circ} \mathrm{C}$ indicates the redbreasted nuthatch must elevate its metabolic rate to equate heat gain with heat loss. The line representing this increase extrapolates to above the range of normal body temperatures, therefore, thermal conductance in this bird probably decreases regularly over a wide range of tempergtures below $30^{\circ} \mathrm{C}$. Such a continuing decrease in conductsnce my be the result of a dacrease in body temperature (Bartholomew, 1964; Dawson, 1958; Dahsor: and Tordoff, 1959, 1964; Hart, 1957, 1962; Herreid and Kesse1, 1967; EIng, 1964; Leitner, 1966; Miseh, 1960; Scholander, 1950b; Veghte, 1964; 
TABLE I--The basal metabolic rate of the red-breasted nuthatch (3.7. $\mathrm{ce} \mathrm{O}_{2} / \mathrm{g} \times \mathrm{hr}-1$ ) and its relationship to predicted values.

\begin{tabular}{|c|c|c|}
\hline EQUATION AND REFERENCES & $\begin{array}{l}\text { PEEDTCTED VALUE } \\
\text { IN } \operatorname{cc} \mathrm{O}_{2} / \mathrm{g} \times \mathrm{hr}^{-1}\end{array}$ & $\begin{array}{l}\text { PERCENT DIFFERENCE } \\
\text { OF THE PREDICTED } \\
\text { VALUE FROM THE } \\
\text { EXPERTMENTAL VALUE }\end{array}$ \\
\hline $\begin{array}{l}\text { Lasiewski-Dawson (1967) } \\
\text { Passerines }\end{array}$ & 3.58 & 3.55 \\
\hline $\begin{array}{l}\text { Lasiewski-Dawsor (1967) } \\
\text { Nonpasserines }\end{array}$ & 2.17 & 41.60 \\
\hline $\begin{array}{l}\text { Lasiewski-Dawson (1967) } \\
\text { A11 birds }\end{array}$ & 3.12 & 15.90 \\
\hline $\begin{array}{l}\text { King-Farner (1961) } \\
\text { Large birds }\end{array}$ & 1.93 & 48.10 \\
\hline $\begin{array}{l}\text { King-Farner }(1961) \\
\text { A11 birds }\end{array}$ & 3.00 & 19.20 \\
\hline $\begin{array}{l}\text { Brody-Proctor (1932) } \\
\text { A11 birds }\end{array}$ & 3.60 & 2.97 \\
\hline $\begin{array}{l}\text { Klei ber (1961) } \\
\text { Mamma 1s }\end{array}$ & 1.69 & 54.50 \\
\hline
\end{tabular}

Veghte and Ferrefd, 1965; West, 1962; West and Hart, 1967). That this nuthatch did lower its body temperature is not known, but this response has been reported regularly in the literature for other small birds (see Introduction). Recouse the body temperatures of these nuthatches were not measured the ambient temperature at which conductance did reach its minimi vilue cannot be determined. Assuming from oxygen consumption data lone, that confuctare in fact did decrease over wide range of mbient temperatures, then these birds could use this response to reduce 
the energy needed for maintaining a constant body temperature during perfods of inactivity tow ambient temperatures.

Because exposure time to ambient temperatures near and below $-15^{\circ} \mathrm{C}$ was short, some of these birds may have resisted dropping their body temp* eratures during these measurements. Therefore, the very high oxygen consunp. tion values of five of these birds may have been the result of higher requirements to maintsin their body temperatures.

During the day the nuthatch obviously produces heat by activity but during cold nights it apparently shivers like other birds to produce the required body heat (Hart, 1962; Steen and Enger, 1957; West, 1965). Shivering movements were observed in nuthatches on the perch of the animal chamber immediately following exposure to cold.

Sever 1 species of birds differ in their ability to increase food consumption and bsorption in response to decreased photoperiod and temper: at ure (Brenner, 1966; Cox, 1961; Davis, 1955; Kendeigh, 1949; Seibert, 1949). The nuthatch probably eats and/or absorbs more food to supply the extra energy it needs to maintain a constant body temperature during the long cold winter night than it needs during the shorter warmer nights of summer. Moore (1945) in discussing the winter night habits of birds mentioned roosting in cavities and other sheltered areas to reduce heat loss. Kendeigh (1961) measured the possible energy conserved by house spartow roosing in nest box and suggested from his results that this behrior may well be the factor allowing the northward extention of many small speciss. Foosting habits of the red-breasted nuthatch are undegcribed but I found than utilizing the nest boxes in the outdoor flight cage on 
two occasions. In congeners, the pigmy nuthatch (Sitta pygmieg) (Knorr, 1957) and brownoheaded nuthetch (Sitta pusilla) (Norris, 1958) communal roosting in cavitios is common.

\section{Oxygen Consumption at High Temperatures.}

The increase in oxygen consumption for (Sitta canaensis) at ambient temperatures bove $39^{\circ} \mathrm{C}$ reflects the energy expended in evaporative cooling. These birds were often observed in the summer, both during captivity and in the wild, hanging upside down with feathers tightly compressed, months ginta and panting.

IV. Oxygen Consumption of Summer and Winter Eixds.

The values for oxygen consumption obtained from the four winter anim fit into the scatter pattern of the values obtained from the 12 summer anima so weIl that no differences are apparent. The smil size of the winter sample may account for this, but because none of the birds tested in these experiments showed any sign of molting, they were probably also in full plumge; therefore differences in oxygen consumption of sumer and winter birds due to diffarences in the insulative quality of the feathers would not be expected. Further experiments determining the survival time at different photoperiods and different ambient temperatures at different seasons when ad lib food is pro vided, may better revel any sesonal metabolic acclimatigation which may occur in this species. 
v. Evaporative Water Loss and Dissipation of Metabolic Heat.

\section{A. Evaporative Water Loss.}

The low rate of water loss of the nuthatch at ambient temperatures below $20^{\circ} \mathrm{C}$ indicates that water loss is a pasive process at these temperatures (Figure 5). The gradual rise in water loss between $22^{\circ} \mathrm{C}$ and $39^{\circ} \mathrm{C}$ probably reflects the ability of warmer air to carry a greater mass of water vapor, rather than it does any active efforts of these birds to lose heat at these ambient temperatures. Furthermore, the record of oxygen consumption (Figure 4) indicates these birds actively produce heat over most of this temperature range so heat loss is not a problem. The bulk of heat lost in this range of moderate temperatures is controlled vis adjust ments of the plumage to facilitate radiation, conduction, and convection. The efficiency of these avenues of heat loss may be further enhanced by dermovascular dilation, and/or elevation of the body temperature to increase the thermal gradient between the body and the environment (Dawson and Schmidt-Nielsen, 1964; Hudson, 1962; Hudson and Bartholomew, 1964; King and Farner, 1964).

The curve for water loss with temperature breaks sharply upward at approximately $40^{\circ} \mathrm{C}$ and indicates that panting must be initiated to prevent accumulation of body heat and elevation of the body temperature.

Laslewski et al (1966) demonstrated that the relative humidity in the metabolism chamber is inversiy related to the rate of the flow of air through it. Whe relative humidity in turn affects the amount of water that can be evaporated from the respiratory surfaces (King and Farner, 1964; 
Lasiewski et al. 1966) and hence directly affects the ability of the bird to dissipate heat by this method. One preliminary experiment diring this study, conducted with relatively low flow rate of 120 cc air/min, and a ambient temperature of $41^{\circ} \mathrm{C}$ illustrated these principles. Moisture in the chamber, resslting from high relative humidity soaked the birds feathers and he survived these conditions only 3 hours. Estimation of the relative humidity in the metabolism chomber used in this experiment, from the formula:

$$
\% \mathrm{RH}=100 \frac{\mathrm{x} / \mathrm{y}}{\mathrm{z}}
$$

given by Lasiewski et $\mathrm{I}$. (1966) where $x$ is the amount of $\mathrm{H}_{2} \mathrm{O}$ vact added in $\mathrm{mg} / \mathrm{min}, \mathrm{y}$ is the $\mathrm{ix}_{\mathrm{x}}$ flow tate in $1 \mathrm{~min}, \mathrm{z}$ is the density of sturated stream at the temperature of the chamber, reveals it was never over $15 \%$ at the flow rate of $620 \mathrm{cc}$ ix/min (uncorrected to STP) used in 11 but the first six of these experiments. Evaporative $\mathrm{H}_{2} \mathrm{O}$ loss was not measured in the first six experiments, and none of them were conducted at ambient temperatures exceeding $39^{\circ} \mathrm{C}$. Because of the wide range of flow rates used throughout the ifterature, and the variations in relative humidity which result, no tempt has been made to directly relate the waigh of water lost by this nuthateh to thet lost by other birds. In gener 1 evorative loss per gram body weight increases invarsely with decreasing body weight in expergl specis (Fertholomew and Dawson, 1953). 


\section{B. Dissipation of Matabolic Heat.}

Because oxygen consumption and water loss were measured simultanousiy in these experiments, the relative effectiveness of the bird"s evaporative cooling can be estimated. This relationship is shown in Figure 8 the e/p ratio (e = the heat lost in calories by evaporative cooling, nd $p=$ the metabolic heat produced in calories) which illustrates the percent of the metabolic heat which is lost by evaporative cooling. The results shown in these experiments indicate quite accurately the effectiveness of evaporative cooling in this species. These nuthetches incregse water loss tremendously at temperatures above $37^{\circ} \mathrm{C}$, and at $42^{\circ} \mathrm{C}$ and $43^{\circ} \mathrm{C}$ they dissipate 74 to $77 \%$ of their metbolic heat by evaporative cooling (Figure 8). Birds generally appear reluctant to lose valuable water for such cooling and store heat by insulative adjustments, thereby raising body temperatures to within tolerated limits and consequently increasing passive heat loss to the environment (King and Firner, 1964). However, if environmental temperatures exceed the body temperatures tolerated by the bird then body heat can only dissipated by evaporative cooling.

Activity reduces the efficiency of evaporative cooling as is demonstrate by the e/p ratio of the winter bird at $42^{\circ} \mathrm{C}$. This bird was active throughw out this test, and had the highest metabolic rate of any bird tested at high ambient temperatures. Consequentig its e/p ratio (Figure 8) mesures sightly over $50 \%$. Feduction in activity and avoidance of direct insol ion, therefore, could we 11 be prexequisites for birds to prevent lethal rise in body temperature when exposed to high ambient temperatures. 
Figure 700 . The e/p ratio for the red-breasted nuthatch plotted with ambi temperoture $\left(\mathrm{T}^{\circ} \mathrm{C}\right)$. See legend for Figure 4 . 


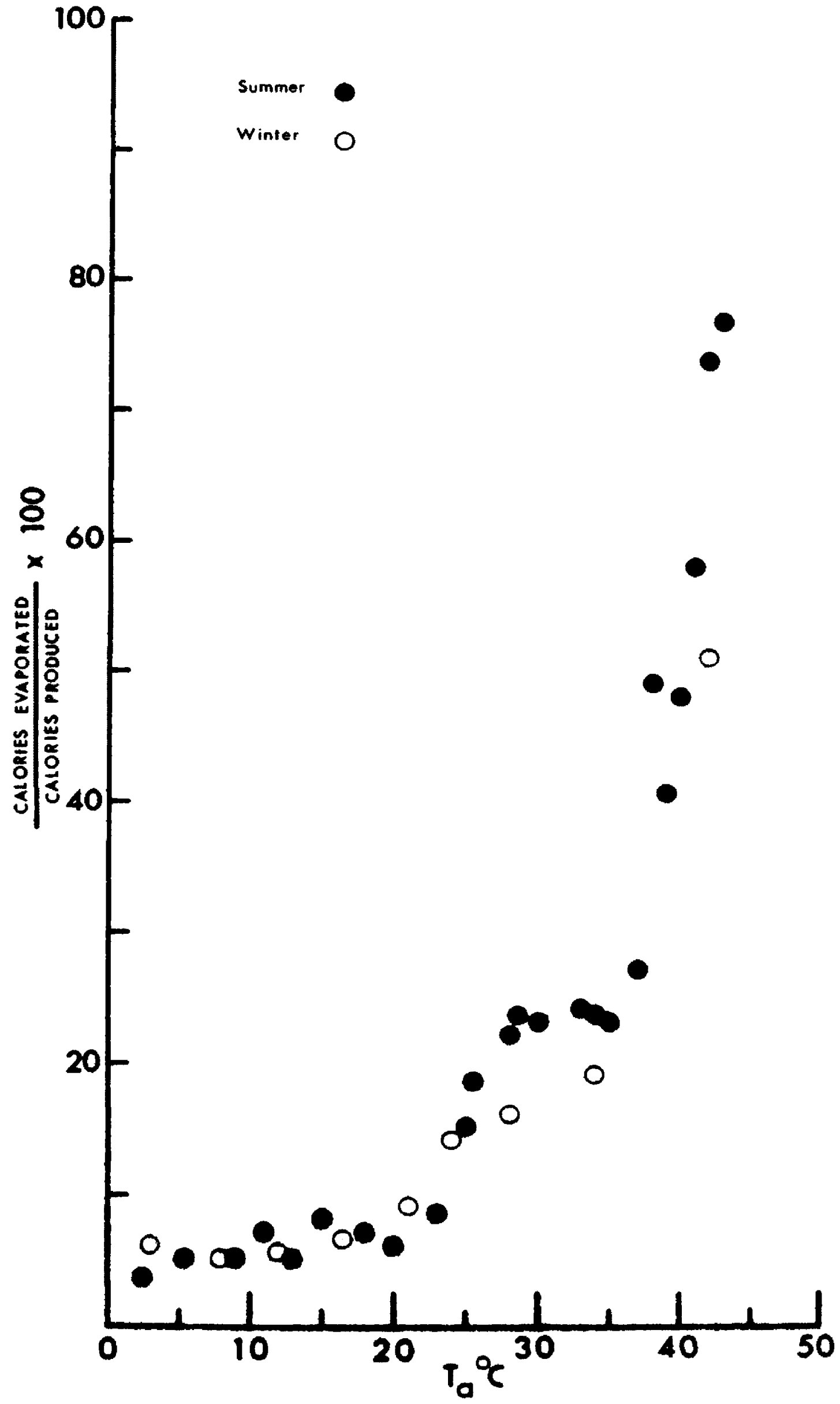

Reproduced with permission of the copyright owner. Further reproduction prohibited without permission. 
vI. The Respiratory Quotient.

Several authors (Rendelgh, 1944; Salt, 1952; nd Wallgren, 1954)

have found that small passerines reach postwabsorptive gt te fter a fagt of 2 to $3 \mathrm{hrs}$, chnreteriged by respiratory quoticnt of around 0.70. Red-brested nuthtches, exposed to mbient temperatures below $26^{\circ}$ always produced respiratory quotients of around 0.70 even when fasted less than two hrs. White ts when exposed to cold have resplratory quotients of around 0.70 even if they are borptive (Fage, 1957; Page and Chtnier, 1953). Though respiratory quotients of this nature supposediy Indicate the catabolism of fats, fats my not always be utilized perferentially or exclusively an energy source since 11 foodstuffis may be used at in increased rate upon short term exposure to cold. But because fat is the major reserve energy source it may be preferentially called upon to balance caloric output when caloric intake is not posible (Masoro, 1966).

The summer nuthatches when exposed for few hours to cold produced a respiratory quotient below 0.75 but when the ambient temperature was elevated they shifted to a respiratory quotient between 0.90 and 1.0 . This shift may indicate that carbohydrates may be available food store even after 4 to $6 \mathrm{hrs}$ of fasting in the cold. Respiratory quotients indicative of fat metabolism my be due to low temperatures affecting the metrolic processes so that linge quantities of $\mathrm{CO}_{2}$ are relesed from the reserves possessed by the animal (Trwing et al, 1930). In one instance, the shift from low to high respir tory quotient did not occur when the temperature was elevated, and either this anim l had reached a true post obsorptive 
state, or the levation of the ambient temperature was not enough to produce the shift.

On long-term exposure to cold in mammals, nonghivering thermeogenesis replaces the shivering thermeogenesis of short term exposure (Hemingway, 1963) but it has rot been determined what particular focdstuffs if any were used to preferentiolly support nonshivering thermeogens is (Masoro, 1966). Steen and Enger (1957), Hart (1962), and West (1965), indicate that non* shivering thermeogenesis does not play role in heat production in birds even after long-term exposure to cold; therefore, cold-acelimatized birds connot ppropritely be compared with cold-accilmatized mammals because of these differences in mechinisms of heat production.

In the winter group, when the temperature of the matabolism was elevated, only one nuthatch shifted from a respiratory quotient below 0.75 to one between 0.90 and 1.0 , and two birds maintaired respiratory quotients between 0.76 and 0.89 . Acclimatization to cold in the winter animals may allow them to use all foodstuffs, not just fat, as the calorigenic agent when they are exposed to low temperatures. Consequently carbohydrates as well fats could be utilized at low ambient temperatures, and the depleted carbohydrate stores would allow a low respiratory quotient to occur when the ambient temperature was elevated.

The respiratory quotient of one of the winter birds taken fter 2.5 hrs of froting at $3^{\circ}$ twos above 1.0 indicating that fat systhesis was ocrur. ing. The ocwurence of respiratory quotient of this nature is not consist. ent with the other dat obtalned during these experiments. It may result from experimental error, or from the release of $\mathrm{CO}_{2}$ from the nimal's reserves (Irving et 1.1930$)$. 
A test was conducted an ambient temperature of $31^{\circ} \mathrm{C}$ with summer animal to determine wher a post absorptive respiratory quotient could be obtained. During the third and fourti hours, the respiratory quotient was above 1.0 and after 5 hrs it was between 0.90 and 1.0 . A similar experiment conducted on winter bird at $34^{\circ} \mathrm{C}$ revealed resplratory quotients below 0.75 at the end of the 2 nd hr, between 0.76 and 0.89 the start of the $4 \mathrm{ch} \mathrm{hr}$, above 1.0 at the start of the $5 \mathrm{th}$ hr, and between 0.90 and 1.0 at the end of the 6 th hr. Why these birds fail to arrave at or maintain postogborptive respiratory quotient during periods of extended fosting at high ambient temperatures is unclear.

At ambient temperstures above $28^{\circ} \mathrm{C}$ for the sumer bieds, respiratory quotients above 1.0 often cccured. The occurence of these high respiratory quotituts in the winter data we les common, though this may be the result of the smoll number of and is for which winter data are awalable. If these respiratory quotients are true indicacion of fat synthesis, their regular occurtence may indicate a helghtened ability during the summer to produce energy $\rightarrow$ rich fat stores.

Respiratory quotient values below 0.65 were repetitive indicating thet they were not grtifgcts of technique (Tabie 2). Those valueg below 0.50 , erept for on at $-6.5^{\circ} \mathrm{c}$ in the winter group, 11 occur at anbinet comperatures below $=150 \mathrm{C}$. These low repiratos quotients mey reflect the trenendow metabolic demidg made upon the se bisds wher moved from Toom tempersture to these extremely low mblent tempertist. 
Table 2-A summry of the sespirtory quotient values below 0.65 .

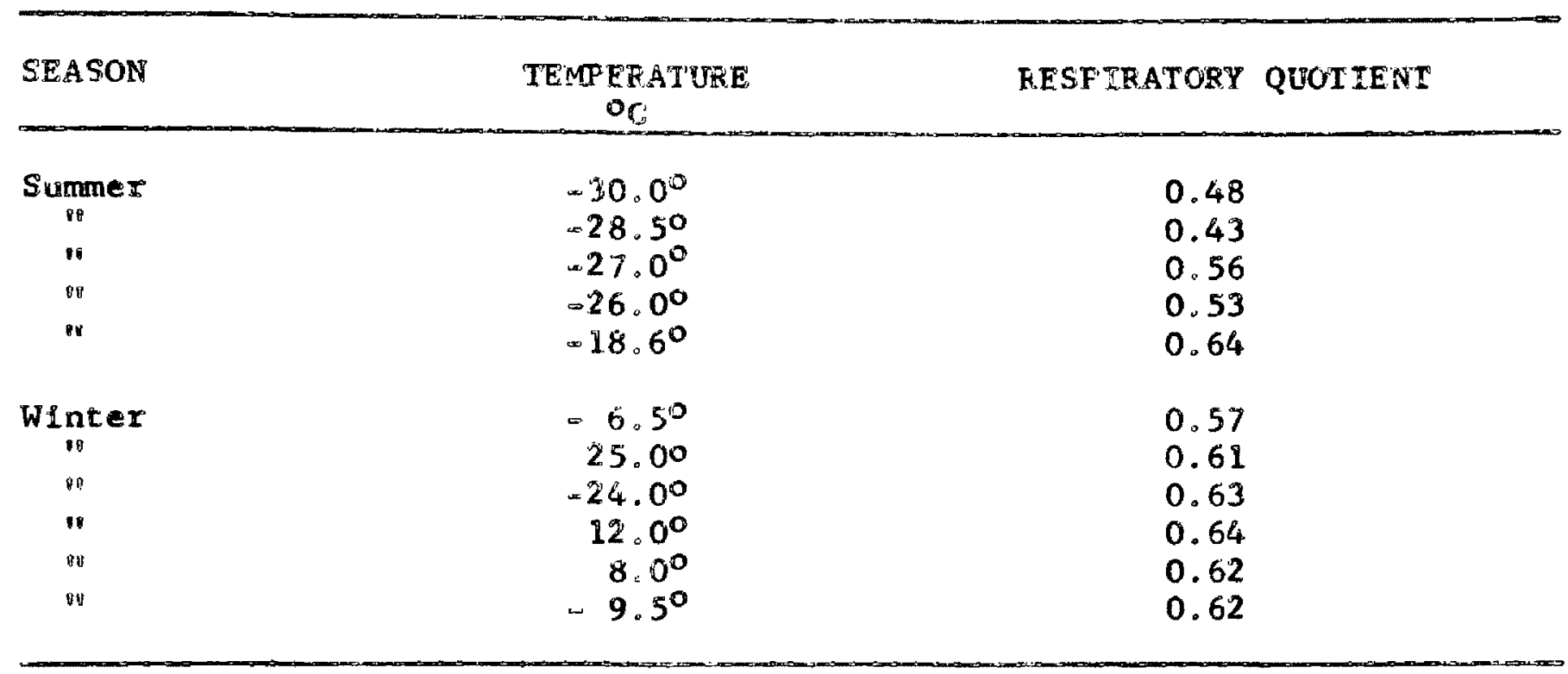

The great variation in respiratory quotients throughout these experw ments illustrates that shortoterm respiratory quotients lone not wid expressions of internediry metrbolism (RLELbr, 1961; Masoro, 1966). They may indicate the $n$ nimel is post-absorptipe at amblent temperatures which allow expression of resting metabolic rate, but when metabolic increases are demanded, the respiratory quotiont may be distorted by any one of the reasons given in the Introduction of this paper. The wide variation of respiratory quoticnts for this speries indicates that the Intermediary metgolism of it and other small birds which are resident in climates requiring regulator of the body temperature over a wide range

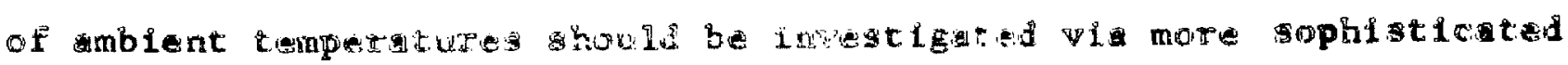
methods. 


$$
82 .
$$

\section{SUMMARY AND CONCLUSIONS}

The red-breasted nuthateh is a resident of the north temperete forests of North Americi. Oxygen consumption, evaporative water loss, and respiratory quotients were messured in this amsil species (9 to $14.2 \mathrm{~g}$ ) to find its seasonal themogenic abilities over temperature range of $730 \mathrm{C}$.

In both sumer and winter birds, oxygen consumption increased with decreasing amblent temperstures below $30^{\circ} \mathrm{C}$ t constant rate of $.20 \mathrm{cc}$ $\mathrm{O}_{2}{ }^{\circ} \mathrm{C}$. Between $30^{\circ} \mathrm{C}$ and $39^{\circ} \mathrm{C}$ the average metabolic rate of $3.71 \mathrm{cc}$ $\mathrm{O}_{2} / \mathrm{g} \times \mathrm{hr}^{-1}$ agrees with the predicted palie for passerines.

The rate of evaporative water loss incressed with increasing ambient tempersture from less than $5 \mathrm{mg} / \mathrm{g} \times \mathrm{hr}^{-1}$ at $2.5^{\circ} \mathrm{C}$ to about 28 $\mathrm{mg} / \mathrm{g} \times \mathrm{hr}-1$ at $43^{\circ} \mathrm{C}$. This rate of water loss ind lestes these birds are capable of regulating their body temperatures, in part, via this method when other avenues of heat 1098 become restricted or unfesible. The red-breasted nuthatch is capdile of dissipating more than $70 \%$ of its metabolic heat through ewaporativo cooling very high mbient temperatures.

Respiratory quotients ranged from 0.43 to 1.3 over the $73^{\circ} \mathrm{C}$ temperature range studied. They indicate thet change in catabolizm occur between low mbient tempertures and high mbient temperatures. A shift of resiratory quotent with rise in ambient temperature is also described. This shift, and other variations in the respirtory quotient are discussed. 


\section{LITERATURE CIIED}

A. O. U. 1957. Che $k$. list of North American Birds. Fifth ed. Amer. Ornitho. Union. The Lord Batimoze Press Inc., Baltimore, Maryland. $691 \mathrm{p}$.

Bakus, G. J. 1959. Observations on the life history of the dipper in Montana. Auk, 76: $190=-207$.

Baldwin, S. P., ard Kerdeigh, S. C. 1932. Physlology of the temperature of birds. Sci. Pub1. Cleveland Muse um of Nat. Hist., 3: 1--196.

Barctt, H. G. and Prizile, E. M. 19:i. Energy and gaseous metabolism of the hen $2 s$ affected ty temperature. Jo Nutrition, 22: 273--286.

and - 1946. Energy and gaseous metabolism of the chicken from hatch to maturity as afected by temperature. J. Nutrition, 31: $35-50$.

Bartholomew, G. A., and Dawson, W. R. 1953. Respiratory water loss in some birds of southwester: lnited States. Physiol. Zool., 26: 162--166.

Bartholomew, G. A., Dawsin, W. R., and $C^{8} N \in 111$, E. J. 1953. A study of temperature regulation in young white pelicans, Pelecanus erythrorynchos. Ecology, 34: $554=-560$.

Bartholomew, G. A. and Dawson. W. R. 1954. Temperature regulation in young pelicans, herons, and gills. Ecology, 35: 466--472. and $\quad 19546$. Eody temperzure and water requirements of the mourrirg Evve, sengldura mecroura marginella. Ecology, 35: 181--187

Bartholomew, T. A. and Cade, T. T. 1957. The body temperature of the American kestre1, Falco spaverius. Wilson Eul1., 69: 149--154.

Bartholomew, G. A. Howe 1 . T. R., ard Cede, T. J. 1957. Torpidity in the white-throted swift, Anna humingbird, and poorwill. Condor, 59: $145=-155$.

Bartholomew, G. A., and Sawson, W. R. 1958. Body temperature in California and GambeI's quial1. Auk 75: 150--156.

Bartholomew, G. A. and Hudson. I. W. 1960. Aestivation in the mohave ground squirrel, Citeliss mohydersis. Eul1. Mus. Comp. Zoo1., 124: 193--208.

Sartholomew, G. A., and Mecmilen, A. E. 1961. Oxygen consumption, estivation, and hibesratien in the knengo mose, Microdipodops pallidus. Physiol. Zoo1., 34: 177 . 183. 
Bartholomew, G. A., Hudson, J. W., and Howe11, T. R. 1962. Body temperature, oxygen consumption. evaporative weter loss, and heart rate in the poorwi11. Condor, 64: $117 m-125$.

Bartholomew, G. A., Leitrer, P., and Telson, I. E. 1964. Body temperature, oxygen consumption. and heart rate in 3 species of Australian Flying Foxes. Ptysicl. 2001., 37: \$79-198.

Bazett, H. C., Love, L., Newton, M. Elsenberg, L., Day, R., and Forster, R. 1948. Temperature changes in blood flowing in arteries and veins in man. J. AFE 1. Physiol., 1: $3-19$.

Bazett, H. C., Mendelson, E. S., Love, L., ard Libet, B. 1948. Precooling of blood in the arteries, effective het capacity and evaporative cooling as factors modifying cocling of the extremities. J. App1. Physiol., 1: $169=-182$.

Beckman. 1962. Made1 G-2 oxyger anaiyzer; Instruction Manua 1, 1043 B. Beckman Instruments Inc.. Scientific and frocess instruments division, Fullerton, California. 45 .

Benedict, F. G. 1938. Vital energetics, (a study in comparative basal metabolism). Carnegie Institute of Washington D.C. $212 \mathrm{p}$.

Benedict, F. G., and lee, R. C. 1937. Lipogenesis in the animal body with a special reference to the physiology of the goose. Carnegie Institute of Washington D.C. $232 \mathrm{p}$.

Brenner, F. J. 1965. Metzooilsm and survival time of grouped starlings at various temperatures. Wilson Bu11.,77: 388--395.

- 1966. Enexgy and nutrient requirements of the red-winged blackbird. Wilson Bu11., 78: $111--120$.

Brody, S. 1945. Bioenergetics and growth. Reinhold, New York. 1023 p.

Brody, S., and Proctor, R. C. 1932. Grewth and development with special reference to domestic animals. XXIII. Relation between basal metabolism and mature body weight in different species of mammals and birds. Missouri Univ. Agr. Exper. Sta. Research Bu11., 166: 89--101.

Burton, A. C., and Edholm, O. G. 1955. Man in a cold environment, (Physiologic: and pathologifal effects of exposure to low temperatures). Edward Arnold, Lomdon L.T.D. 273 P.

Brush, A. H. 1965. Ervergetics, temperatore, regualtion, and circulation in resting, active, and dofothered California quail, Lophortyx californicu: Comp. Eiachem. and Physiol., 15: 399- -421 .

Cade, T. J., Tobin, C.A., and Gold, A. 1965. Water economy and metabolism , Estrildine finches. Physiol. Zoo1., 38: 9--33. 
Calder, W. A. 1964. Gaseous metabolism and water relations of the zebra finch, Taeniopygia castanotis. Physiol. Zool., 37: 400--413.

Calder, W. A., and King, J. R. 1963. Evaporative cooling in the zebra finch. Separatum Experientia, Birkhauser Verlag, Basel (Schweiz), 19: 603-606.

Calder, W. A., and Schmidt-Nielsen, K. 1966. Evaporative cooling and respiratory alkalosis in the pigeon. Proc. Nat. Acad. of Sci., 55: 750--756.

Chaffee, R.R.J., Mayhew, W. W., Drebin, M., and Cassuto, Y. 1963. Studies on thermogenesis in cold acclimated birds. Canadian J. Biochen. and Physio1., 41: 2215--2220.

Chaffee, R. R. J. and Mayhew, W. W. 1964. Studies on thermoregulation in the house sparrow (Passer domesticus). Can. J. of Physiol. and Pharmacology 42: $863--866$.

Chatfield, P. O., Lyman, C. P., and Irving, L. 1953. Physiological adaption to cold of peripheral nerve in the leg of the herring gull (Larus argentatus). Amer. J. Physiol., 172: 639--644.

Cottle, W. H., and Carlson, L. D. 1956. Regulation of heat production in cold adapted rats. Proc. Soc. Exp. Biol. and Med., 92: 845--849.

Cowles, R. B., and Dawson, W. R. 1951. A cooling mechanism of the Texas nighthawk. Condor, 53: 19--22.

Cox, G. W. 1961. The relation of energy requirements of tropical finches to distribution and migration. Ecology, 42: 253--266.

Davis, E. A. 1955. Seasonal changes in the energy balance of the English sparrow. Auk, 72: 385--411.

Davis, T. R. A. 1960. Shivering and nonshivering heat production in mamma is and man. Cold Injury Trans. 6th Conf. Josiah Macy, Jr. Foundation.

Dawson, W. R. 1954. Temperature regulation and water requirements of the brown and abert towhees, Pipilo fuscus, and Popilo aberti. Univ. Ca1if. Publ. Zoo1., 59: 81--124.

- 1958. The relation of oxygen consumption and evaporative water loss to temperature in the cardinal. Physiol. Zool., 31: 37--48.

Dawson, W. R., and Evans, F. C. 1957. Relation of growth and development to temperature regulation in nesting fleld, and chipping sparrows. Physio Z.

Dawson, W. R. and Tordoff, H. B. 1959. Relation of oxygen consumption to temperature in the evening grosbeak. Condor, 61: 388--346. 
Dawson, W. R, and Evans, F. C. 1960. Relation of growth and development to temperature regulation in nestling vesper sparrows. Condor, 62: $329=-340$.

Dawson, W. R., and Tordoff, H. B. 1964. Relation of orygen consumption to temperature in the red and white-uinged crossbills. Auk, $81: 26-35$.

Dawson, W. R., and Schridt-Nielsen, K. 1964. Terrestrial animals in dry heat: desert birds. 481--492 pp. In: Handbook of Physiology (D. B. Dili, Ed Sec. 4: Adaptation to the Environment. Amer. Physiol. Soc., Washington D. C.

Depocas, F. and Hart. J. S. 1957. Use of the Pauling oxygen analyzer for measurement of oxygen consumption of animals in open circut systems and in short-lag, closed-circuit apparatus. J. App 1. Physiol, 10: $388--392$.

Depocas, F., Hart, J. S., and Héroux, 0. 1957. Energy metabolism of the white rat after acclimation to warm and cold environments. J. Appl. Physiol., 10: $393--397$.

DuBois, E. R. 1936. Bas 1 Metabolism in Health and Disease. Philadelphia, Le and Febiger. 494 p.

Edholm, O. G. 1961. Hypothermia and the effects of cold, Introduction. Brit. Med. Bu11., 17: 1--4.

Farner, D. S. 1956. Body temperature of the fairy prion (Pachyptila turtur) in flight and test. J. App1. Physiol., 8: 546--548.

Freeman, B. M. 1966. The effects of cold, noradrenaline and adrenaline upen the oxygen consumption and carbohydrate metabolism of the young fow 1 (Gallus domest1cus). Comp. Blochem. and Physio1., 18: 369--382.

French, N. R., and Hodges, R. W. 1959. Torpidity in cave roosting hummingbirds Condor, 61: 232 .

Gelineo, S. 1964. Organ systems in adaptation: The temperature regulating system. 259--282 pp. In: Handbook of Physiology (D. B. Di11, Ed.) Sec. 4: Adaptation to the environment. Amer. Physiol. Soc., Washington $D$. C.

Hamme1, H. T. 1955. Thermal properties of fur. Am. J. Physio1. 182: 369--376

Hardy, J. D. 1961. Physiology of temperature regulation. Physiol. Rev. 41: $521-606$.

Hart, J. S. 1956. Seasonal changes in insulation of the fur. Can. J. Zoo1.。 34: $53=-57$.

- 1957. Cilmatic and temperature induced changes in the energetios of homeotherms. Rev. Can. Biol., 16: 133--174. 
Hart, J.S. 1962a. The physiology of mammalian cold acclimation. 203-242 pp. Comparative Physiol. of Temp. Reg. (Hannon and Viereck, Ed.) Arctic Aeromedical Lab., Fort Walnwright, Alaska.

$.1962 \mathrm{~b}$. Seasonal acclimatization in four species of small wild birds. Phys101. Zool., 35: 224--236.

- 1964 Geography and season: mammals and birds. 295--321 pp. In: Handbook of Physiology (D. B. Dill, Ed.) Sec. 4: Adaptation to the environment. Amer. Phys1ol. Soc., Washington D.C.

Hart, J. S., Heroux, O., and Depocas, F. 1956. Cold acclimation and the electromyogram of unanesthetized rats. J. App 1. Physio1., 9: 404--408.

Hart, J. S., and Irving, L. 1959. The energetics of harbor seals in air and in water with special consideration of seasonal changes. Can. J. Zool., 37: $447--457$.

Hemingway, A. 1963. Shivering. Physio1. Rev., 43: 397--422.

Henry, K. M., Magee, H. E., and Reid, E. 1934. Some effects of fasting on the blood and respiratory exchange in fow 18. J. Exper. Biol., 11: 58-72.

Hock, R. J. 1951. The metabolic rates and body temperatures of b2ts. Biol. Bul1., 101: 289--299.

Howe 11, T. R. 1961. An early reference to torpidity in a tropical swift. Condor, 63: 505.

Howe11, T. R., and Bartholomew, G. A. 1959. Further experiments on torpidity in the poorw111. Condor, 61: 180--185.

and

- 1961a. Temperature regulation in nesting Bonin Is land petrels, wedge-tailed shearwaters, and Christmas Island shearwaters. Auk, 78: 343--354.

and - 1961b. Temperature regulation in laysan and blackfooted ibatrosses. Condor, 63: 185--197.

and - 1962. Temperature regulation in the red-tailed tropic bird nd redofooted booby. Condor, 64: 6--18.

Hudson, J. W. 1962. Temperature regulation in desert birds and mammals. 4?! $-447 \mathrm{pp}$. Comp. Physiol, of Temp. Reg. (Hannon and Viereck, Ed.) Aret1t: Aeromedica 1 L boratory, Ft. Wainwright, Alaska.

- 1964. Temperature regulation in the round-tailed greund squirred. Citallas tereticaudus. Ann. Academiae Scientiarum Fennice, Series A. W. Giologica,71/15, Heisinki. Suomalaineu, Tiedegkatemia: 219:0233. 
Hudson, J. W. 1965. Temperature regulation and torpidity in the pygmy mouse, Biomys toylori. Physiol. Zool., 38: 243--254.

Hudson, J. W. and Rumme1. J. A. 1966. Water metabolism and temperature regulation of the primitive heteromyids. Liomys salvani, and Liomys irroratus. Ecology, 47: 345--354.

Hudson, J. W., and Bartholomew. G. A. 1964. Terrestrial animals in dry heat: estivators. 541-550 PF. In: Handbook of Physiology (D. B. Dill Ed.) Sec. 4: Adaptation to the environment. Amer. Physiol. Soc., Washington D. C.

Hudson, J. W., and Brush, A. M. 1964. A comparative study of the cardiac and metabolic performance of the dove Zenaidura macroura, and the quail, Lophortyx californicus. Comp. Biochem. and Phys1o1., 12: 157--170.

Huxley, J. S., Webb. C. S., and Best, A. T. 1939. Temporary poikilothermy in birds. Nature, 143: 683--684.

Irving, L. 1955. Nocturnal decline in the temperature of birds in cold weather. Condor, 57: $362-365$.

- 1956. Physiological insulation of swine as bare-skinned animals. J. of App 1. Physio1., 93: $414--420$.

- 1960. Birds of Anaktuvak Pass, Kobuk, and 01d Crow (a study in arctic adaptation). U. S. Nat. Mus. Bull. 409 p.

- 1962. The heterothermous condition of the tissues of warmoblooded anima 1s. 133--174 pp. Comp. Physiol. of Temp. Reg. (Hannon and Viereck, Ed.) Arctic Aeromedical Laboratory, Ft. Wainwright, Alaska.

- 1964. Terrestrial animals in cold: birds and mammals. 361-a377. In: Handbook of Physiology (D.B..Dill, Ed.) Sec. 4: Adapt ton to the environment. Amer. Physiol. Soc., Washington D. C.

Irving, L., Ferguson, J. K. W., and Plewes, F. B. 1930. The source of carbon dioxide expired and the site of its retention. Physiol., 69: 113--123.

Irving, L. and $\operatorname{Krog}_{p}$ J. 1954. Body temperatures of arctic and subarctic birds and mamals. J. of App1. Physiol., 6: 667--680.

Irving, L., Krog, F., and Monson, M. 1955. The metabolism of some Alaskan anims is in winter and summer. Physiol. Zool., 28: 173,o185.

Irving, L., snd Krog, J. 1955. Temperature of skin in the arctic as regulator of heat. J. of App 1. Physio1., 7: 355--364.

Irving, L., Krog, J. Krog, H., and Monson, M. 1956. Metabolism of varying hare in winter. J. of mamme 1., 38: 527- -529 . 
Irving, L., Payton, L. J., and Monson, M. 1956. Metabolism and Insulation of swine as bare-skinned mammals. J. of App1. Physiol., 9: 421--426.

Irving. L., and $\mathrm{Krog}$, J. 1.956. Temperature during the development of birds in arctic nests. Physiol. Zoo1, 29: 195--205.

Irving, L. and Hert, T. S. 1957. The metabolism and insulation of seals as bare-skinned mamm is in cold water. Can. J. of Zool., 35: 497--511.

Irving, L., Peyton, L. J., Bahn, C. H., and Peterson, R. S. 1962. Regulation of temperature in fur seals. Physiol. Zool., 35: 275--284.

Jaeger, E. C. 1948. Does the poorwil1 hibernate? Condor, 50: 45--46.

- 1949. Further observations on the hibernations of the poorwill. Condor, 51: 105- 109 .

Johansen, K. 1961. Heat exchange through the skin in the tail of the muskrat, Ondatra zibethicus. Fed. Proc. 20: 110.

Kah1, M. P. 1963. Thermoregulation in the wood stork, with special reference to the role of the legs. Physiol. Zool., 36: 141--151.

Kayser, C. 1937a. Les lipids assurent préférentiellement 1a thermogenése de . réchauffement chez le cobaye. Compt. Rend. Soc. Biol., 126: 701-0704.

- 1937b. Variations du quotient respiratoire en fonction de la temp. du milieu chez le rat, le pigeon, et le cobaye. Compt. Rend. Sac. Biol., 126: 1219.

Kendeigh, S. C, 1934. The role of environment in the life of birds. Ecol. Monographs, 4: 299--417.

- 1939. Relation of metabolism to the development of temperature regulation in birds. J. Exper. Zool, 82: 419--438.

- 1944. Effect of air temperature on the rate of energy metabolism in the English sparrow. J. Exper. Zoo1., 96: 1--16.

- 1949. Effect of temperature and season on energy resources of the English sparrow. Auk, 66: 113--127.

- 1961. Energy of birds conserved by roosting in cavities. Wilson Bu11., 73: $140--147$.

King, J. R. 1957. Comments on the theory of indirect calorimetry as applied to birds. Northwest Science, 31: 155--169. 
King, J. R. 1964. Oxygen consumption and body temperature in relation to ambient temperature, in the white crowned sparrow. Comp. Blochem. and Physiol. 12: 13--24.

King. J. R.o and Faxner, D. S. 1961. Energy metabolism, thermoregulation, and body temperature. 215--288 pp. In: Biol. and Comp. Physiol. of Birds (Marsha11, Ed.) Vol. 2. Academic Press, New York and London.

, and 1964. Terrestrial animals in humid heat: birds. 603--624 FP. In: Handbook of Physiology, (D. B. Dill, Ed.) Sec. 4: Adaptation to the environment. Amer. Physio1. Soc., Washington D. C.

Kleiber, M. 1961. Fire of 1ife. Wiley, New York. 435 p.

- 1964. Respiratory exchange and metabolic rate. 927-0938 pp.

In: Handbook of Physlology (Fenn and Rahn, Ed.) Sec. 3, Vol. 2:

Respiration. Amer. Physiol. Soc., Washington, D.C.

Knorr, 0. A. 1957. Communal roosting of the pigmy nuthatch. Condor 59: 398.

Kreyberg, L. 1949. Development of acute tissue damage due to cold. Physiol. Rev., 29: 156- -167 .

Krog, A. 1916. The respiratory exchange of animals and man. Longmans, Green, London.

Krog, H., Monson, M., and Irving, L. 1955. Influence of cold upon the metabolism and body temperature of wild rats, lbino rats, and albino rats cono ditioned to cold. J. of App 1. Physiol., $7: 349=-354$.

Lasiewski, R. C. 1963. Oxygen consumption of torpid, resting, active, and flying hummingbirds. Physiol. Zool., 36: 122--140.

- 1964. Body temperature, heart and breathing rate, and evaporstive weter loss in himmingbirds. Physiol. Zool., 37: 212--223.

Lasiewki, R. C. and Dawson, W. R. 1964. Physlological responses to temperature in the common nighthawk. Condor, 66:477--490.

Lasiewski, R. C. Hubbard, S. H., and Moberly, W. R. 1964. Energetic relationships of a very small passerine bird. Condor, 66: 212,00220.

Lasiewski, R. C. and Thompson, H. J. 1966. Field observations of torpidity in the violet green swallow. Condor, 68: 102- 103 .

Lasiewsk, R. U., and Bartholomew, G.A. 1966. Evaporative cooling in the poorwill and the tawny frogmouth. Condor, 68: 253-w262. 
Lasiewski, R. C., Acosts, A. L., and Bernstein, M. 1966. Evaporative water loss in tirds. I. Characteristics of the open flow method of determination, and their relation to estimates of thermoregulatory ability. Comp. Biochem. and Fhysiol., 19: 445--457.

Lasiewski, R. C. and Dawson, W. R. 1967. A re-examination of the relation between standird metabolic rate and body weight in birds. Condor, 69: $13--23$.

Leitner, P. 1966. Body temperature, oxygen consumption, heart rate, and shivering in the California mastiff bat. Eumops perotis. Comp. Biochem. and Fhysiol., 19: 431--433.

Lusk, G. 1919. Elements of the science of nutrition. Saunders, Philadelphia. $641 \mathrm{p}$.

Macmillen, R. E. 1965. Aestivation in the cactus mouse Peromyscus eremicus. Comp. Biochem. Physiol., 16: 227--248.

Marsha11, J. T. Jr. 1955. Hibernation in captive goatsuckers. Condor, 57: $129--134$.

Masoro, E. J. 1966. Effect of cold on metabolic use of lipids. Physio1. Rev., 46: $67--101$.

McAtes, W. L. 1947. Torpidity in Birds. Am. Midl. Nat., 38: 191--205.

McNab, B. K. 1966. An nas lys of the body temperatures of birds. Condor. 68: $-47--55$.

Mellen, W. J. and Hill, F.W. 1955. Studles of the avian respiratory austiert. Poultry Sci., 34: 1085--1089.

Misch, M. S. 1960. Heat regulation in the northern blue jay Cyanocitta cristata bromia, Oberholser. Physiol. Zoo1., 33: 252--259.

Moore, A. D. 1945. Winter night habits of birds. Wilson Bul1。, 57: 253--260.

Morrison, P. R., and Ryser, F. A. 1951. Temperature and metabolism in some Wisconsin mammis. Fed. Proc., 10: 93.

Morrison, P. R. 1962. Modification of body temperature by activity in Brayilian hummingbirds. Condor, 64: $315--323$.

Odum E. P. 1942. Muscle tremor and the development of temperature regulation in birts. Amer. J. Fhysiol., 136: 618--622.

Page, E. 1957. Body composition and fat deposition in rats acclimated to colj. Rev. of Can. Fiol., 16: 269--278. 
Page, E., and Chenier, L. 1953. Effects of diet and cold environment on the R. Q. of the white rat. Rev. Can. Biol., 12: 530--541.

Pearson, O. P. 1960. Torpidity in birds. Bull, of the Mus. of Comp. Zool., 124: $93--103$.

Randa11, W. C. 1943. Factors influencing the temperature regulation of birds. Am. J. Fhysiol., 139: 46--63.

Salt, G. W. 1952. The relation of metabolism to climate and distribution in three finches of Carpodacus. Ecol. Monographs, 22: 121--152.

Salt, G. W., and Zeuthen, E. 1960. The respiratory system. $363--409$ pp. In: Biol. and Comp. Physiol. of Birds, (Marshall, Ed.) Vol. 1: Academic Press, New York.

Scholander, P. F. 1955. Evolution of climatic adaptation in homeotherms. Evolution, 9: 15--26.

Scholander, P. F., Witers, V., Hock, R., and Irving, L. 1950a. Body insulation of some arctic nd tropical mammals and birds. Biol. Bull., 99: 225 236 .

Scholander, P. F., Hock, R., Walters, V., Johnson, F., and Irving, L. 1950b. Heat regulation in some arctic and tropical mammals and birds. Biol. Bul1., 99: 237--258.

Scholander, P. F., Hock, R., Walters, V., and Irving, L. 1950c. Adaptation to cold in arctic and tropical mamals and birds in relation to body temperature, insulation, and basal metabolic rate. Biol. Bul1., 99: $259--271$.

Seibert, H. C. 1949. Differences between migrant and nonmigrant birds in food and water intake at various temperatures and photoperiods. Auk, 66: $128--153$.

Sellers, E. A.s Scott. J. W., and Thomas, N. 1954. Electrical activity of skeletal muscles of normal and acclimated rats on exposure to cold. Amer. J. Physiol. 177: 372m-376.

Semat, H. 1962. Fundament ls of physics, 3rd Ed.: Holt, Rinehart, and Winston, New York. 914 p.

Shellabarger, G. J. Lastewskt, R. C., and Hyncik, G. E. 1961. Thyrold function in active seping and torpid tummingbirds. Nature, 191: 1318.

Stebbins, R. C. 1957. A further observation on torpidity in the foorwill. Consc: 59: 212 .

Steen. T. and Engs:, P. S. 1957. Muscular hest production in pigeons during exposure to cold. Amer.J. Physiol., 191: 157--158. 
Steen, J. 1958. Climatit adaptation in some small northern bizds. Ecology. 39: $625-629$.

Steen, I., and Steen, J. B. 1965A. The importance of the legs in the thermo regulation of birds. Acta Physiol. Scand., 63: 285-0291. - and 1965b. Thermoregulatory importance of the beaver's tail. Comp. Biochem. and Physio1., 15: 267--270.

Thorburg, F. 1953. Another hibernating poorwi11. Condor, 55: 274 .

Thorington, R. W. Jr. 1966. The biology of rodent tails. A atudy of form and function. Arctic Aeromedical Laboratory, TR $-65-8: \quad 1=-137$.

Tucker. V.A. 1962. Diurnal torpidity in the california pocket mouse ( californicus). Science, 136: $380-=381$.

United States Department of Interior Geological Survey 1903 . Contour Maps Montana, Bonner Quadrangle, N $46030^{\prime}$, W $113^{\circ} 30^{\prime} / 30$.

Veghte, J. H. 1964. Thermal and metabolic responses of the grey jyy to cold stress. Physiol. Zool. 35: 316--328.

Veghte, J. H., and Herreid, C.F. 1965. Radiometric determination of feather insulation and metabolism of arctic birds. Physiol. Z001.8 38: 267.w275.

Wallgren, H. 1954. Energy metabolism of two species of the genus Emberize, as correlated with distribution and migration. Acta Zool. Fenrlea, 84: $1--110$.

West, G. C, 1962. Responses and aptations of wild birds to environment I temperature. 291--333 pp. In: Comp. Physiol. of Temp. Reg. (Hannon and Viereck, Ed.) Arctic Aeromedical Lab., Fort Wainwright, Aliska. - 1965. Shivering and heat production in wild birds. Physiol. Z0ol., 38: $111--119$.

West, G. C., and Haxt, J. S. 1966. Metabolic responses of evening grosbeaks constant and to fluctuating temperatures. Physiol. Zoo1., 39: 171-0184.

Wetmore, A. 1921. A study of the body temperature of birds. Smithsonian Misc. Co11., 72: 10-52. 